\title{
Sosyal Medya ve Hedonik Tüketimin Tüketici Tutumu ve Tatmin Üzerindeki Etkisi
}

\author{
Ali KÖROĞLU ${ }^{1}$ ve Salih YILDIZ ${ }^{2}$
}

$\ddot{O} z$

Günümüzde internet hızla yaygınlaşmakta ve internet kullananların oranı da hızla artmaktadır. İnsanlar internet aracılı̆̆yyla mal ve hizmet satın almakta, ürünlerle ilgili bilgi sahibi olmakta ve ürünlerle ilgili fikirlerini internet üzerinden paylaşmaktadır. İnsanların bu faaliyetleri gerçekleştirdikleri internet araçlarından biri de sosyal medyadır. İnsanlar sosyal medyada karşılaştıkları içeriklerden etkilenmekte ve bu durum mal ve hizmetlere karşı tutumlarında belirleyici olmaktadır. Bu çalışmanın amacı sosyal medyanın hedonik tüketim üzerindeki etkisini ve hedonik tüketimin tutum ve tatmin üzerindeki etkisini belirlemektir. Bu amaçla araştırmanın ana kütlesi olarak Sakarya ilinde ikamet eden tüketiciler belirlenmiştir. Evrenin büyük olması nedeniyle seçilecek örneğe ulaşmayı kolaylaştırmak için kolayda örnekleme yöntemi kullanılmıştır. Bu doğrultuda Sakarya'da yaşayan 391 kişiye anket uygulanmıştır. Anketler katılımcılarla yüz yüze olarak gerçekleştirilmiştir. Elde edilen verilerin faktör analizi ve güvenilirlik analizleri SPSS 21 programında yapılmıştır. Modelin uygunluğu ve değişkenler arası ilişkiler ise AMOS 24 programında analiz edilmiştir. Analizler sonucunda sosyal medyanın hedonik tüketim üzerinde pozitif etkisi olduğu tespit edilmiştir. Ayrıca hedonik tüketimin de tutum ve tatmin üzerinde pozitif etkisi olduğu sonucuna ulaşılmıştır.

Anabtar Kelimeler: Sosyal Medya, Hedonik Tüketim, Tüketici Tutumu, Tatmin

\section{The Effect of Social Media and Hedonic Consumption on Consumer Attitude and} Satisfaction

\section{Abstract}

In the present day, the internet is spreading rapidly and the rate of internet users is increasing speedily. People buy goods and services, get information and share ideas concerning the products via the internet. One of the internet tools where people carry out these activities is social media. People are influenced by the content they encounter on social media, and this situation determines their attitude towards goods and services. This study is aimed to determine the effect of social media on hedonic consumption and the effect of hedonic consumption on attitude and satisfaction. For this purpose, the consumers residing in Sakarya were determined as the main part of the study. The convenience sampling method is applied to facilitate access to the sample to be selected due to the large population size. Accordingly, a survey was applied to 391 people living in Sakarya. The surveys were conducted face to face with the participants. Factor analysis and reliability analysis of the data obtained were analyzed in SPSS 21 program. The appropriateness of the model and the relationships between variables were analyzed in AMOS 24 program. As a result of the analysis, it has been determined that social media has a positive effect on hedonic consumption. In addition, it is concluded that hedonic consumption has a positive effect on attitude and satisfaction.

Key Words: Social Media, Hedonic Consumption, Consumer Attitude, Satisfaction

\section{Atıf İçin / Please Cite As:}

Köroğlu, A. ve Yıldız, S. (2021). Sosyal medya ve hedonik tüketimin tüketici tutumu ve tatmin üzerindeki etkisi. Manas Sosyal Arastirmalar Dergisi, 10(2), 1106-1123.

Geliş Tarihi / Received Date: 14.08.2020

Kabul Tarihi / Accepted Date: 05.02.2021

\footnotetext{
${ }^{1}$ Öğr. Gör. - Türkiye-Tokat Gaziosmanpaşa Üniversitesi Adalet Meslek Yüksekokulu, ali.koroglu@gop.edu.tr

iD ORCID: 0000-0003-4021-6300

2 Doç. Dr. - Türkiye-Gümüşhane Üniversitesi iktisadi ve İdari Bilimler Fakültesi, salihyildiz@gumushane.edu.tr

(iD) ORCID: 0000-0002-1002-5960
} 


\section{Giriş}

Günümüzde internetin hızla gelişmesi ve geniş alanlarda kullanılmaya başlanması firmaların da interneti pazarlama faaliyetlerinde kullanmasını sağlamıştır. Firmalar internet siteleri kurarak bu sitelerden satışlar yapmanın yanı sıra internetin sunmuş olduğu farklı imkanlardan da pazarlama faaliyetleri çerçevesinde faydalanmaktadırlar. Bu imkanların en önemlilerinden biri de sosyal medyadır. Firmalar sosyal medyayı bir pazarlama aracı olarak kullanmanın yanında onu bir halkla ilişkiler aracı olarak da kullanmaktadırlar. Sosyal medya sayesinde firmalar müşterileri ile daha hızlı ve daha az maliyetle iletişim kurmaktadırlar (Yıldız ve Avc1, 2019, s. 180). Mevcut müşteriyi elde tutmak yeni müşteri kazanmaya kıyasla daha az maliyetli olduğundan firmalar mevcut müşterilerini ellerinde tutmaya büyük önem vermekte ve müşterileri ile sürekli iletişim halinde olmaya çalışmaktadırlar. Firmaların müşterileri ile iletişim kurmak için kullandığı kanallardan biri de sosyal medyadır (Avcı ve Yıldız, 2019, s. 86).

Sosyal medya aracilı̆̆1 ile firmalar mal ve hizmetleri hakkında müşterilerini bilgilendirmekte, ürünlerinin reklamını yapmakta, mal ve hizmetleri hakkında müşterilerinden geri bildirim almakta ve bu bildirimler doğrultusunda iyileştirmeler yaparak kalitesini artırabilmektedir. Ayrıca sosyal medya günümüzde kulaktan kulağa pazarlamanın dijital mecradaki karşıllğı olarak da görülmektedir. Müşteriler satın aldıkları mal ve hizmetlerle ilgili fikirlerini sosyal medya sitelerinde paylaşarak diğer müssterileri etkileyebilmektedir.

Sosyal medya tüketici güdülerini harekete geçirerek tüketicilerin algılarını da etkileyebilmektedir. Tüketiciler yeni ürünler, yeni trendler ve moda ile ilgili gelişmeleri sosyal medyadan takip edebilmekte, hiç ihtiyacı olmadığı halde sosyal medyada gördüğü bir ürünü satın almak isteyebilmekte, sosyal medyadan takip ettiği bir ünlünün giymiş olduğu bir elbiseye veya takmış olduğu bir takıya sahip olmak isteyebilmektedir. Sosyal medya fenomenlerinden etkilenebilmekte ve onlar tarafindan yönlendirilebilmektedir. Ayrıca tüketiciler yeni deneyimler ve yeni maceralar yaşamak için sosyal medyada etkileşimlerde bulunabilmektedir. Kısaca tüketicilerin sosyal medya kullanım durumu onları hedonik tüketime yönlendirebilmektedir.

Hedonik güdüler, tüketicilerin tutumları ve alısveriş sonucunda elde ettikleri tatmin üzerinde etkili olan birçok faktörden biridir. Tüketicilerin sosyal medya kullanım davranışları sonucu oluşan hedonik tüketim alışkanlıkları onların tüketim tutumları üzerinde de etkili olabilmektedir. Tüketiciler yeni trendleri takip etmek, macera yaşamak, değer verdikleri insanları mutlu etmek, stres atmak, rahatlamak, sosyal ilişkiler kurmak, alısverişten ve alışveriş sürecinden zevk almak için alısveriş yapabilmektedirler. Dolayısıyla bu ihtiyaçlarını karşılamaya yönelik faaliyetler geliştiren firmalara karşı daha olumlu tutum geliştirebilmektedirler. Bu ihtiyaçlarını karşılamak onlara yüksek bir tatmin düzeyi sağlayabilmektedir.

"Tüketicilerin sosyal medya kullanımından etkilenen hedonik tüketim davranışları onların tutum ve tatminlerini etkileyebilir mi?” sorusu, bu araştırmanın temel problemini oluşturmaktadır. Bu çalışma sosyal medyanın hedonik tüketim üzerindeki etkisini ve hedonik tüketimin; tüketici tutumu ve tatmini üzerindeki etkisini incelemek amacıyla internet üzerinden alışveriş yapan tüketiciler üzerinde gerçekleştirilmiştir.

\section{Sosyal Medya}

Son yıllarda Web 1.0 uygulamalarından Web 2.0 uygulamalarına yani yeni nesil Web'e geçilmesiyle internet uygulamaları çok fazla etkileşim içeren bir platforma taşınmışırı (Koçak, 2012, s. 16). Bu gelişme yani web 2.0'a geçilmesi sosyal medyanın temellerinin atılmasına zemin hazırlamıştır. Her ne kadar Web 2.0 sosyal medyayla aynı anlamda kullanılıyor olsa da Web 2.0 sosyal medyanın ortaya çıkmasını sağlayan teknolojik gelişmelere işaret etmektedir (Bulut, 2012, s. 25). Web 2.0 insanların bilgiyi çevrimiçi paylaşmasına olanak sağlayarak insanları sosyalleştirmekte ve bilgisayarlar aracilığılla etkileşim kurarak sanal topluluklar oluşturmalarına olanak tanımaktadır (Cook ve Buckley, 2008, s. 277).

Web 2.0 ile temelleri atılan sosyal medya kavramı ilk olarak Tom Truscott ve Jim Ellis tarafindan 1979 yllında geliştirilen ve dünya genelindeki internet kullanıcılarıla mesajlaşma imkanı sunan Usenet isimli bir tartışma platformuyla ortaya çıkmıştır. Kavramın günümüzdeki anlamıyla kullanılması ise 1998 yilında Bruce ve Susan Albeson tarafindan Open Diary isimli ilk sosyal ağ iletişim sitesinin kurulmasıyla başlamışır. Bu site günlük olarak yazılar yazan insanları bir araya getirerek topluluklar oluşturmalarını sağlamaktadır. Bundan sonra da gerek internetin hızlı bir şekilde yaygınlaşması ve gelişmesi gerekse popüler kültürün hakimiyetini artırmasıyla farklı isimlere sahip ve farklı özellikler barındıran birçok sosyal ağ sitesi kurulmuş ve bugünkü sosyal medya terimi ortaya çıkmıştır (Kaplan ve Haenlein, 2010, s. 60). 
Sosyal medya temel olarak insanların belirli bir yöntem veya cihaz aracillğıyla birbirleriyle ilişkileri neticesinde ortaya çıkan ve devam ettirilen iletişim veya yayın sistemleri ile ilgilidir (SI, 2016, s. 1). Sosyal medya katılımcılara sınırlı bir sistem içerisinde yarı yarıya veya tamamen kamuya açık profil oluşturma, bağlantı halinde oldukları başka kullanıcıların içeriklerini açık seçik görebilme, başkalarının bağlantılarını görüntüleme ve engelleme imkanı veren hizmetler bütünü olarak tanımlanabilir (Boyd ve Ellison, 2007, s. 211). Başka bir yaklaşımla ele alındığında ise katılımcılara çevrimiçi platformlarda kendilerini ifade edebilme, başkaları ile iletişim kurabilme, farklı gruplara üye olma, fikirlerini, yorumlarını veya yayınlarını paylaşabilme imkânı sunan sosyal içerikli web siteleridir (Köksal ve Özdemir, 2013, s. 325).

Mayfield (2010, s. 5) sosyal medyanın özelliklerini, katılımcları cesaretlendirmesi ve ilgili kullanıcılardan geri bildirim alınmasına imkan vermesi; geri bildirime ve katılımcılara açık olması, oylama, yorum ve bilgi paylaşımı konularında nadiren engeller koyması; iki yönlü konuşmaya olanak tanıması; topluluklara hızlı ve etkili bir oluşum imkanı sağlaması; bağlantılı işler gerçekleştirmesi ve başka siteler veya araştırmalarla ilgili link verilmesine olanak sağlaması olarak sıralamaktadır. Kısaca sosyal medyanın Özellikleri katılımcılar, açıklık, konuşma, toplum ve bağlantıllık olarak sıralanmaktadır.

Kim, Jeong ve Lee (2010, s. 218) de sosyal içerikli web sitelerinin özelliklerinin kişisel profil, online bağlantı kurma, online gruplara katılma, online bağlantılarla iletişim kurma, kullanıcıların oluşturduğu içeriği paylaşma, fikir ve yorumda bulunma, bilgi edinme ve kullanıcıları sitede tutma olduğunu belirtmektedir. Sosyal içerikli web siteleri; kullanıcılarının kişisel bilgilerini içeren bir profil oluşturmalarını istemekte, onları daha önce etkileşimde bulundukları kişilerle iletişime geçmeye teşvik etmektedir. Ayrıca kullanıcıların online gruplar oluşturmalarını ve bu gruplara katılmalarını sağlamakta, başkalarıyla telefon görüşmesi de dahil iletişime geçme imkanı sunmaktadır. Kullanıcılar sosyal içerikli web sitelerinde; kendilerine ait içerikleri başkalarıly paylaşabilmekte, haber bilgi, video ve resim gibi içeriklere fikir ve yorum yazabilmektedirler. Birçok site çevrimiçi olmadan da kişi bilgi ve içerik hakkında arama yapılmasına ve paylaşımda bulunulmasına imkan vermekte ve kullanıcıları sitede daha uzun süreler tutmak için birçok özellik geliştirmektedir.

Sosyal medya insanlara kendilerini tanıma fırsatı ve başka insanlarla tanışma veya daha önceden tanıştıkları insanlarla iletişimlerini devam ettirme imkanı sağlamaktadır. Sosyal medya iletişim ve ilişkiyi güçlendirip sürdürülmesini sağlayarak kişilerarası iletişime katkıda bulunmaktadır (Çalışır, 2015 s. 119).

Sosyal medya tüketici davranışları üzerinde de etkili olabilmektedir. İç ve dış uyarıcılar sonucunda ihtiyaç algılayan tüketici satın alma karar sürecini başlatır ve daha sonra bu ihtiyaçları ile ilgili bilgi toplamaya başlar. Sosyal medya bilgi toplama aşamasında, tüketicinin fiyatları ve alternatifleri karşılaştırmasının yanısıra tüketicinin ürün hakkında bilgi sahibi olmasını da sağlar (Aytan ve Telci, 2014 s. 3).

Sosyal medya işletmeler açısından da büyük önem taşımaktadır. Teknolojinin gelişmesiyle bilgi, bireyler arasında hızlı bir şekilde taşınmakta, rekabet ve satış konularında işletmeler hedeflerine ulaşabilmek için stratejilerini hızlı bir şekilde uygulamaktadırlar. İşletmenin büyüklügünnden ziyade stratejilerini hızlı bir şekilde uygulayabilmesi, pazar payını yükseltmesinde etkili olmaktadır. İşletmeler sosyal paylaşım ağları aracilığıla tüketiciye hızlı bir şekilde ulaşabilmekte ve aynı şekilde tüketiciler de işletmeyle iletişime geçebilmektedirler. Bu şekilde sosyal ağları kullanarak tüketiciye hızlı bir şekilde ulaşan işletmeler rekabet avantajı elde etmektedirler (Terkan, 2014, s. 60). Ayrıca işletmeler Facebook ve Twitter gibi sosyal paylaşım sitelerindeki resmi sayfalarının yapısı ve tasarımıyla ve bu sayfalarda gerçekleştirdikleri faaliyetlerle tüketicilerde güven oluşturabilmekte ve markalarına yönelik tüketici bağllil̆ğ1 sağlayabilmektedirler (Haciefendioğlu, 2014, s. 61). Isşletmeler sosyal ağlar, bloglar, microbloglar, video ve resim paylaşım siteleri, podcastler, wikiler ve emailing gibi internet tabanlı sosyal medya kanallarında maliyetsiz etkinlikler yaparak, müşterilerle etkileşime geçip, onların fikir ve önerilerine hızlı bir şekilde ulaşarak rekabet avantajı elde etmektedirler (Köksal ve Özdemir, 2013, s. 326). Sosyal medyanın tüketiciler tarafından yoğun bir şekilde kullanılıyor olması işletmelerin bu alanda etkin olmasını zorunlu kılmaktadır. Örneğin en fazla takipçisi olan sitelerden Faceebok günümüzde bir milyardan fazla kullanıcıya sahiptir. Benzer şekilde Linkedln 259 milyon, Twitter 500 milyon kullanıcıya ulaşmıs durumdadır. Kullanıcı sayısı bir milyarı aşan YouTube'de ise günde dört milyar video paylaşımı yapılmaktadır (Toksarı, Mürütsoy ve Bayraktar, 2014, s. 6). Sosyal medyadaki bu yoğunluk nedeniyle firmaların bu mecralarda faaliyet göstermeleri ve bu mecraları kullanan tüketicilerle etkileşime geçerek tüketicilerde güven oluşturmaları firmalar açısından oldukça önemlidir. Ancak tüketicilerde bu mecralar aracıllğ̣yla güven ve bağlllık oluşturmak, işletmelerin sosyal medyayı etkili bir şekilde kullanması ve yönetmesine bağlıdır. 
Altındal (2013, s. 1087-1088) sosyal medya yönetiminde; etkileşim, değer ve pazarlama olarak üç önemli unsur bulunduğunu belirtmektedir. Etkileşim, sadece müşterilere değil, müşteri olma potansiyeli olan insanlara da sosyal medya aracillğıyla bilgiler vermek ve bu insanların mal ve hizmetlere yönelik sorularını cevaplandırmaktır. Değer, sosyal paylaşımlarla takipçilere katma değer katmak, bu yönde aktiviteler yapmaktır. Örneğin firma kendi faaliyet alanına ilişkin bilgiler içeren bir blog sayfası oluşturur ve bu sayfada ele aldığı konuların başlıklarını sosyal medyada paylaşarak takipçileri blog sayfasına yönlendirir. Aynı şekilde blog sayfasındaki bilgilerle de takipçi, firmanın web sitesine yönlendirilir. Sosyal medya her ne kadar bir reklam platformu olmasa da sosyal medyadaki yoğunluğun çok fazla olması sebebiyle firmalar buralarda da reklamlar yapabilmekte marka ile ilgili haberlerini ve promosyonlarını buralardan paylaşabilmektedirler. Böylece sosyal medya firmaların pazarlama faaliyetlerine de katkıda bulunmaktadır.

\section{Hedonik Tüketim}

Günümüzde tüketim fizyolojik ihtiyaçları giderme amacını taşıyan bir aktivite olmanın yanında insan yaşamının ve kişiliklerin şekillenmesinde de rol oynamaya başlamışıtır. Dolayısıyla Maslow'un ihtiyaçlar hiyerarşisinde en alt basamaktaki fizyolojik ihtiyaçlardan yukarıdaki basamaklara çıkıldıkça tüketim de boyut değiştirmektedir. Birey ilk basamağı çıktığında fizyolojik ihtiyaçlarını karşılamış, dolayısıyla da faydacı tüketim gerçekleştirmiş olur. Yukarı basamaklara çıkıldıkça hedonik tüketim gerçekleştirerek kişisel ihtiyaçlarını karşılar (Şengün ve Karahan, 2013, s. 18; Bakırtaş ve Divanoğlu, 2013, s. 1524).

Buradan hareketle bireylerin ihtiyaçlarını karşılamak için gerçekleştirdikleri iki farklı tüketim türünden söz edebiliriz. Bu tüketim türleri faydacı tüketim ve hedonik(hazc1) tüketimdir. Faydacı tüketim insanların fizyolojik ihtiyaçlarını karşılamaya yönelikken, hedonik tüketim kendilerini gerçekleştirme ihtiyacına yöneliktir. Bu nedenle tüketim deneyiminin anlaşılabilmesi için faydacı bakış açısı kendi başına yeterli değildir. Tüketim davranışlarının anlaşılabilmesi için hedonik bakış açısına da ihtiyaç vardır (Mathews, Ambroise ve Brignier 2009, s. 3).

Hedonizm, faydacılıktan istek ve gereklilik konusunda farklılaşmaktadır. Faydacılık bireyin yaşamını devam ettirmesine yardım eden zorunluluklara dayaliyken, hedonizm haz, arzu ve istek gibi duygulardan beslenir (Okada, 2005, s. 43). Hedonizm hayattaki en önemli şeyin zevk olduğuna işaret eder ve acıdan kaçınır (O’Shaughnessy ve O'Shaughnessy, 2002, s. 526). Kişilere, toplumlara ve durumlara göre farklılıklar içerebilen hedonizmin temel düşüncesi bireyin yaşamının merkezinde bulunan haz ve tatminin üst seviyelere çıkartılmasıdır. Hedonist bireylere göre onları acıdan uzaklaştırıp hazza ulaştıran yolların her biri iyi ve güzeldir (Sarıtaş, 2018, s. 38). En genel şekliyle tanımlanacak olursa hedonizm, zevk, memnuniyet ve hazzın birey yaşamındaki en önemli değerler olduğunu savunan, keyif arayışı üzerine kurulu bir hayat tarzı doktrinidir. Maddi tasarruflar ve uygunluk faydacı değerin tanımlanmasında kullanılırken, hedonik değerin tanımlanmasında kışkırtma, zevk, eğlence, fantezi ve keyif arayışı gibi kavramlar kullanılır (Hopkinson ve Pujari, 1999, s. 274; Köker ve Maden, 2012, s. 100; Adomaviciute, 2013, s. 756).

Geleneksel olarak hedonizm, felsefi hedonizm ve psikolojik hedonizm olmak üzere iki kısımda incelenmektedir (Fromm, 2008, s. 3). Felsefi hedonizm, bireylerin hazzı en yüksek seviyeye çıarmayı amaç edindiklerini ve bunun için çaba harcadıklarını savunur. Onlara göre haz veren her şey iyidir ve mutluluk verir. Psikolojik hedonizm ise güdülenme ile açıklanan bir kavramdır. Bu görüşte de haz iyi bir şeydir ve bireyler hazza ulaşma isteğine sahiptir. Psikolojik hedonizme göre bu isteğin varllğını ve her bireyin bu isteği tatmin etme hakk1 bulunduğunu kabul etmek gerekir (Odabaş1, 2009, s. 108-109).

Hedonizm tüketim açısından ele alındığında ise hedonik tüketim kavramı ortaya çıkmaktadır. Bu kavrama göre hazzı bir amaç olarak benimseyen tüketiciler hedonik olarak isimlendirilmektedir. $\mathrm{Bu}$ tüketicilerde haz arayışı devamlı sürdüğu için bir davranış haline gelmektedir (Özdemir ve Yaman, 2007, s. 81). Günümüzde bireyler sadece fayda amacıyla alı̧veriş yapmamaktadırlar, satın aldıkları şeylerden haz almak istemektedirler. Satın aldıkları mal veya hizmetin kendilerini mutlu etmesini beklemektedirler. Başka bir ifade ile bireyler için tüketimin duygusal boyutu da önem kazanmaktadır. Bireyler artık alışveriş yaparken, alısverişin işlevselliği yanında sağlayacağı duygusal tatmini de göz önünde bulundurmaktadırlar (Akgül ve Varinli, 2017, s. 7).

Hedonik tüketim, ilkel benliğin etkisi sonucu mal veya hizmet ile hayal gücü boyutunda ve duygusal olarak bir tecrübe olarak tanımlanabilir (Babacan, 2001, s. 97). Buradan hareketle tüketimden elde edilen hazda duygusal uyarımın büyük bir etkisi olduğu söylenebilir. Ancak hedonizmi tanımlamakta sadece duyum yoluyla elde edilen algilar yeterli değildir. Hedonik tüketimde tüketicilerin marka veya ürün tarafından gönderilen uyarıcıları zihinlerinde bir imaja dönüştürmesi sonucu, işlevsel fayda algisı sembolik 
fayda alg1sı ile güçlendirilmektedir. Böylece tüketicinin tüketim sonucunda elde ettiği hoşnutluk artmaktadır (Şen ve Boyraz, 2017, s. 354). Bu nedenle hedonik tüketim; arzu ve fantezilerle harmanlanan, sürekli bir şekilde arzu edilen ve tatmin olmak asla mümkün olmayan, duyulardan ziyade duygularla hareket etmeye yönelik eğilimin olduğu bir tüketim tarzı olarak tanımlanabilir (Arslan, 2016, s. 275).

Hedonik tüketimde ürünün neyi temsil ettiği ne olduğundan daha önemlidir. Bu kavram ürünleri nesnel varlıklar olarak değil öznel semboller olarak tanımlar. Hedonik tüketim ürünün tüketici nezdinde taşıdığ imaja odaklanır ve tüketicinin ürüne verdiği duygusal tepkiye önem verir. Tüketiciler ürünün belirgin ve somut niteliklerine özel anlamlar eklerler. Tüketicinin ürüne ekleyeceği öznel semboller ürünün belirgin ve somut özelliklerinden daha önemlidir (Baş ve Samsunlu, 2015, s. 19). Bazı insanların yılbaşı alışverişinde kendini şekerleme dükkânında bulunan bir çocuk gibi hissetmeleri, oyuncak almayı sevenlerin içlerindeki çocuğa vurgu yapmaları veya bazı insanların sorunlarından uzaklaşmak için alışveriş yaptıklarını ifade etmeleri; alışverişin ürünü elde etmekten fazlası olduğunu (Babin, Darden ve Griffin, 1994, s. 646) ve tüketicilerin ürüne ve alışverişe yüklediği öznel anlamları göstermektedir.

Hedonik tüketim; sesler, duygusal izlenimler, tatlar ve görsel imajlar gibi duygu imgeleri ve fantezilerle ilgilidir. Bu duygu imgeleri, gerçek bir olayı hatırlatır ya da bir olayla ilgili öznel bir anlam taşırlar. Bazı ürünlerin tüketiminde duygusal heyecanlar tüketiciye önemli ölçüde güdü sağlar (Hudson ve Murray, 1986, s. 343-344).

İnsanları hedonik tüketime yönelten güdüler; içsel veya dışsal olabildiği gibi, bireysel veya toplumsal da olabilir. Tüketicileri hedonik alısverişe yönelten bireysel faktörler; ürünleri daha ucuza alabilme isteği, fiziksel aktiviteler, duyusal uyarımlar, eğlenceler, kişisel haz sağlama isteği vb. nedenler olarak saylabilirken, toplumsal faktörlere örnek olarak da; toplumdaki saygin kişilerden etkilenme, toplumsal deneyim kazanma isteği, iletişim kurma isteği, görüssme ve referans gruplarından etkilenme vb. nedenler gösterilebilir (Baş ve Samsunlu, 2015, s. 19).

İnsanlar ürünleri satın alırken sadece işlevselliğini dikkate almazlar, ürünün onlar için ifade ettiği anlamı da göz önünde bulundururlar (Hirschman ve Holbrook, 1982, s. 92). Bu durum hedonik tüketimi faydacı tüketimden ayıran temel noktalardan biridir. Yani tüketiciler, tüketimden faydanın yanında haz sağlamayı da amaçlamaktadırlar. Fayda amacı güden tüketicilerde ürünün nesnel özellikleri ve işlevselliği önemlidir. Hedonik tüketicilerse eğlenceyi, duygusal ve anlamlı tepkileri, heyecan ve zevk veren mal ve hizmetleri, estetik ve hazzı ön plana alır ve hedonik tüketim bu mal ve hizmetlerin tüketim aşamasında gerçekleşir (Sarıtaş, 2018, s. 39; Kükrer, 2011, s. 79). Faydacı tüketim hedonik tüketimle kıyaslandığında daha rasyonel, tutarlı ve bilgi edinmeyle daha fazla alakalıdır (Hanzaee ve Irani, 2011, s. 7450). Bunun sebebi; faydacı tüketimin malın kalite fiyat uygunluğu, çeşitlilik ve kazanç arayışıla motive ediliyor olmasıdır (Petljak, Stulec ve Rudawska, 2015, s. 186). Hedonik tüketimde ise ürünün işlevsel faydasından ziyade sembolik faydası önemlidir. Dolayısıyla insanlar daha sık alışveriş yapmaktadırlar. Hedonik tüketimle ilgili çalışmalar, tüketicilerin alışveriş esnasında duygusal beklentilerinin faydacı nedenlere baskın geldiğini göstermektedir (Coley, 2002, s. 33).

Fakat tüketicilerin sadece faydacı veya sadece hedonik güdülerle satın alma işlevini gerçekleştirdiğini düşünmek doğru değildir. Bu alanda yapilan çalışmalar; tüketicilerin gerek algilama, gerekse ürünü tercih etme aşamasında faydacı ve hedonik beklentilere aynı anda sahip olduğunu göstermektedir (Dhar ve Wertenbroch, 2000, s. 60). Tüketiciler satın alma işlevini gerçekleştirirken, bu beklentilerden biri diğerine baskın gelebilmektedir. Bu baskınlık ise kişiye veya duruma göre değiş̧ebilmektedir.

\section{Tutum}

Tüketici, kişisel istek ve ihtiyaçları doğrultusunda mal ve hizmetleri satın alan ya da satın alma gücüne sahip olan kişi olarak tanımlanabilir (Karabulut, 1981, s. 25). Bu doğrultuda tüketici; giderilmesi gereken bir ihtiyac1, harcayabileceği parası ve harcama isteği olan kişi veya kurumdur. Tüketici ve müssteri kavramları birbirine karıştırılabilmektedir. Müşteri, tüketiciden farklı olarak bir kurumdan sürekli olarak bir mal veya hizmeti satın alan kişidir (İslamoğlu, 2003, s. 5).

Tutum; bir kişinin herhangi bir durumu, kişiyi, fikri, hareketi ya da nesneyi sevip sevmeme ve kabul edip etmeme konusunda yapılan genel bir değerlendirme ve karar verme olarak tanımlanmaktadır (Haddock ve Maio, 2008, s. 114). Tutumlar belirli bir nesneye yönelik olarak gerçekleştirilen pozitif veya negatif öğrenilmiş tepkilerdir. Kalıcı ve sürekli olma eğilimi taşırlar. Tutumlar genel ve önemlidirler. Kişilerin düşüncelerini ve duygularını etkileyerek davranışlarına yön vermektedirler. İnsanlar kararlarını 
tutumlara dayalı olarak vermektedirler (Hawkins ve Mothersbaugh, 2010, s. 392; Solomon, Bamossy, Askegaard ve Hogg, 2006, s. 165; Hoyer ve MacInnis, 2008, s. 122).

Tutumlar çeşitli unsurların etkisiyle oluşmaktadır. Bu unsurlar; inançlar, değerler, bağlantı kurma, çağrışım ve bağdaştırma şeklinde sıralanabilir. Tutumları insanların fikir ve düşünce geliştirmesindeki etkileri nedeniyle inançlardan, değerlerden, fikirlerden ve duygulardan ayırmak mümkün değildir (Koç, 2013, s. 234; Ünal, 2008, s. 52).

Tutumlar davranış geliştirme ve niyetlerin belirlenmesinde önemli bir etkiye sahiptirler (Dabholkar, 1994, s. 100). Bu nedenle tüketicilerin karar vermesinde önemli rol oynarlar. Odabaşı ve Barış (2007, s. 164-166), tüketici tutumlarının özelliklerini şu şekilde sıralamışlardır;

1- Güç Derecesi: Tüm tutumlar belirli bir güce sahiptir. Yerleşmiş tutumlar ve onları oluşturan bileşenler diğer tutumlara oranla daha güçlüdürler ve güçlü tutumları değiştirmek daha zordur. Bireylerin siyasi görüşleri ve destekledikleri futbol takımları tutumların güçlü hissedilmesine örnek olarak verilebilir.

2- Karmaşıklık: Tutumlar bileşenlerine göre de farklılaşabilirler. Bileşenlerinin karmaşık veya yalın olmasına bağlı olarak tutumlar da karmaşık ve yalın olabilirler.

3- Bileşenler Arası Tutarlılık: Tutumların bileşenleri arasında genellikle bir tutarlılık söz konusudur. Tutumlar arasında tutarsızlı̆ı̆n mevcut olması, tutum değişikliğine neden olabilir.

4- Diğer Tutumlarla İlişki ve Merkezilik: Bireylerin tutumları diğer tutumlarla ilişkileri açısından farklılık gösterebilir. Bazı tutumların birbiri ile ilişkisi sıkı iken bazı tutumların ilişkisi daha kopuk olabilir.

5- Tutumlar Arası Tutarlılı: Tutumlar arası tutarlılık şart olmamasına rağmen, tutumlar arasında genellikle bir tutarll11k söz konusudur.

6- Tutumlar Öğrenilirler: Tutumların gelişmesinde aile, sosyal ilişkiler, arkadaş çevresi, deneyimler, bilgi vs. etkili olmaktadır.

7- Kişiler Tek Bir Tutum Değil Tutumlar Bütünü Oluştururlar: Örneğin buzdolabına karşı geliştirilen tutum; buzdolabının stili, rengi, rahatlığı ve fiyatı gibi farklı özelliklerine karşı oluşturulan bir bütün olarak düşünülmelidir.

8- Tutumlar Değiştirilebilirler: Tutumlar öğrenilebilir, dolayısıyla değiştirilmeleri mümkündür. Ancak olumsuz tutumların değiştirilmesi diğerlerine oranla daha zor ve pahalıdır.

Tutumlar, bireylerin amaçlarına ulaşmasını sağlamak ve ihtiyaçlarını karşılamasına yardım etmek için oluşmaktadırlar. Yani tutumların bazı işlevleri vardır (Odabaşı ve Barış, 2007, s. 166). Tutumların işlevlerinden birincisi Jeremy Bentham'ın kurucusu olduğu faydacılık teorisine dayanan fayda işlevidir. Esasen bu işlev, insanların diş ortamlarındaki ödülleri en üst düzeye çıkarmak ve cezaları en aza indirgemek için çabaladıkları gerçeğinin tanınmasıdır. İnsan, ihtiyaçlarını karşılayan nesnelere karşı olumlu tutumlar geliştirirken, onu engelleyen ya da onu cezalandıran nesnelere karşı olumsuz tutumlar geliştirir. Ekonomik durumunu geliştirecek bir siyasi partiyi tercih eden işçinin tutumları, birincil faydacı tutumun bir örneğidir. Kișinin en sevdiği yiyeceklere karșı tutumu, ikincil faydacı tutumun bir örneğidir. İkincisi kişiyi kendisi ve dış dünyayla ilgili zorluklara karşı koruyan ego savunma işlevidir. Kişinin öz imajını korumaya yönelik bir işlevdir. Böylece kişinin kendisine saygısı da korunmuş olmaktadır. Freudcu psikoloji ve neo-freudcu düşünce bu tür motivasyon ve sonuçlarıyla ilgilenmiştir. Bir diğer işlevi, bireyin, kişisel değerlerine ve fikirlerine uygun tutumları ifade etmekten memnuniyet duyduğu değer ifade edici işlevdir. $\mathrm{Bu}$ işlev, kendini ifade etme, kendini geliştirme ve kendini gerçekleştirmenin önemini vurgulayan ego psikolojisi doktrinlerinin merkezinde yer alır. Sonuncusu ise, bilgi işlevidir. Bilgi işlevi; anlam arayışı, anlama ihtiyacı, ayrıca birey için açıklık ve tutarlılık sağlamak için algıların ve inançların daha iyi organize edilmesine yönelik eğilim şeklinde tanımlanabilir (Katz, 1960, s. 170-171)

Tutumlar; duygusal, davranışsal ve bilişsel olmak üzere üç temel bileşenden oluşur. Tutumların duygusal bileşeni, bir tutum nesnesiyle ilişkili duygu veya duyguları ifade eder. Duyuşsal tepkiler tutumları çeşitli şekillerde etkiler. Duyguların tutumları etkilemesinin birincil yolu, tutum nesnesine maruz kaldıktan sonra bireyde uyandırılan duygusal tepkiler yoluyla olmaktadır. Örneğin insanların çoğu örümceklerden korktuğunu söyler. Örümceklere karşı bu olumsuz duyguları nedeniyle onların örümceklere karşı olumsuz tutumlar geliştirmesi muhtemeldir. Tutumların bilişsel bileşeni, belirli bir nesneyle ilişskilendirilen inanç, düşünce ve nitelikleri ifade eder. Birçok durumda, bir kişinin tutumu öncelikle tutum nesnesiyle ilgili 
olumlu ve olumsuz niteliklerin dikkate alınmasına dayanabilir. Örneğin, bir kişi yakın zamanda yeni bir otomobil aldığında, farklı araçların güvenlik kayıtları, yakıt tüketimi, yeniden satıs değeri ve onarım maliyetleri gibi faktörlere çok daha fazla önem vermeye başlar. Tutumların davranışsal bileşeni, bir tutum nesnesiyle ilgili geçmiş davranışları ifade eder. Örneğin, insanların daha önce yaşadıkları yerin yakınında bir nükleer enerji santrali kurulmasına karşı bir dilekçe imzaladıkları hatırlanırsa, nükleer enerji santrallerine karşı olumsuz bir tutumları olduğu söylenebilir (Haddock ve Maio, 2008, s. 115-116).

\section{Tatmin}

Müşteri memnuniyeti, bir ürünün, alıcının beklentilerine göre değer sağlamadaki algılanan performansına bağlıdır. Müşterilerin beklentileri ile işletmelerin gerçekleştirdikleri arasındaki farkın olumlu, olumsuz veya eş değer çıkması durumuna göre müşterilerin tatmini veya tatminsizliği söz konusu olmaktadır. Ürünün performansı müşterinin beklentilerinin alında kalıyorsa müşteri memnun kalmaz, performans beklentileri karş̧lıyorsa tatmin olur. Performansın beklentileri aştı̆̆ı durumda ise müşteri mutlu olur. Seçkin pazarlama şirketleri, müşterilerini memnun etmek için şirket politikalarının da dişına çıkabilirler. Memnun müşterilerin tekrar satın aldıklarını ve başkalarına ürünle ilgili iyi deneyimlerini anlattıklarını bilirler. Burada kilit nokta, müşteri beklentilerini şirket performansıyla eşleştirmektir. Bunun farkında olan şirketler, yalnızca sunabileceklerini vaat ederek, daha sonra vaat ettiklerinden daha fazlasını sunarak müşterileri memnun etmeyi amaçlamaktadır (Kotler, Wong, Saunders ve Armstrong, 2005, s. 10; Onaran, 2013, s. 41).

Giderek daha sofistike ve değer bilincine sahip tüketiciler ile tatmin edici düzeyde performans gösteren birden fazla marka göz önüne alındığında, memnun müşteri üretmek işletmeler için zorunlu hale gelmiştir, ancak bu yeterli değildir. Müşterilerin tatmin edilerek kararlı ve işletmeye sadık hale getirilmesi gerekmektedir (Hawkins ve Motherbaughs, 2010, s. 640). Müşterilerin işletmeye sadık olmasını sağlamanın ilk aşaması tatmin edilmeleridir. Tatmin edilmiş müşteriler işletmeye daha sadık olmakta ve satın aldıkları mal ve hizmeti veya hizmeti sunan işletmeyi yakın çevrelerine de tavsiye ederek işletmenin imajına olumlu yönde katkıda bulunarak, işletmenin müşterisinin ve satışlarının artmasını sağlamaktadır. Tatmin olmuş müşteriler, tatmin olmuş çalışanları da beraberinde getirmektedir. Müşterileri tatmin olmuş işletmelerde, çalışma ortamı daha sağlıklı ve huzurlu olmaktadır ve müşteriler de daha çok bu tür işletmeleri tercih etmektedirler (Odabaşı, 2000, s. 118).

Modern pazarlama yönetimi ve toplam kalite yönetiminde müşteri memnuniyeti oluşturma süreci ile ilgili farklı birçok yaklaşım mevcuttur. Bu yaklaşımların hepsinde zaman içerisinde müşteriler ve müşterilere ait zevk ve ihtiyaçlar değiştiği halde, ihtiyaçların tespiti noktasındaki yaklaşımlar değişmemektedir. Müşteri memnuniyeti oluşturma modeli; müşterilerin tanımlanması, ihtiyaçlarının ve beklentilerinin belirlenmesi, algılamalarının ölçümü ve harekat planının gerçekleştirilmesi olarak birbirini dairesel bir şekilde takip eden dört aşamadan meydana gelmektedir (Öz, 2011, s. 98).

Müşteri tatmininin başlıca unsurları beklentiler, istekler ve algılanan performanstır. Bu faktörlerin bilinmesi işletmenin amacına ulaşması açısından önemlidir. Çünkü müşteri tatmini bu faktörlerden etkilenmektedir.

Müşterilerin herhangi bir hizmete yönelik arzu ve ihtiyaçlarını ifade eden faktör, beklentilerdir (Tütüncü, 2001, s. 51). Beklentiler; müşterinin geçmişteki satın alma deneyimlerine, arkadaşların ve iş arkadaşlarının görüşlerine, pazarlamacı ve rakip bilgileri ve vaatlerine dayanır. Pazarlamacılar, doğru beklentileri belirlemeye dikkat etmelidir (Kotler, Wong, Saunders ve Armstrong, 2005, s. 465). Tek (1999, s. 216) beklentilerin tecrübelerden etkilendiğini belirtmektedir. Müşteri beklentileri kimi zaman çevreden, kimi zaman da işletmeden sağlanan birikim sonucunda elde edilir. Müşterilerin beklentilerinin fazlalı̆̆1 oranında, işletmenin müşterileri memnun etmesi zorlaşır (Zeithaml, 2017, s. 187).

İşletmeler beklentileri çok düşük ayarlarlarsa, sadece yeterince tatmin olmamış müşterileri cezbedebilirler. Buna karşılık, beklentileri çok yükseltirlerse, alıcıların hayal kırıklığına uğraması muhtemeldir. Örneğin, Holiday Inn birkaç yıl önce sürekli olarak sorunsuz konaklama ve hizmet vaat eden 'Sürpriz Yok' adlı bir kampanya yürütmüştür. Bununla birlikte, Holiday Inn misafirleri bir dizi sorunla karşılaşmış ve kampanyanın yarattığ beklentiler müşterileri daha memnuniyetsiz hale getirmiştir. Bunun sonucunda Holiday Inn kampanyayı geri çekmek zorunda kalmıştır. Yine de, günümüzün en başarılı şirketlerinden bazıları beklentileri artırmakta ve buna uygun performans sağlamaktadır. Bu şirketler toplam müşteri memnuniyetini benimsemektedir. Örnek olarak, Honda'nın, "Müşterilerimizin bu kadar memnun olmasının bir nedeni, memnun olmamamızdır" veya Dan Technology'nin "İșinize değer veriyoruz. Bizden 
tekrar satın almanızı istiyoruz.” sloganları verilebilir. Bu şirketler yüksek hedefler koymaktadırlar çünkü yüksek derecede tatmin olan müşterilerin daha iyi bir alternatif bulduklarında mevcut tedarikçilerini kolaylıkla değiştirebileceklerini bilmektedirler (Kotler, Wong, Saunders ve Armstrong, 2005, s. 466).

İstek ise, hissedilen ihtiyacı tatmin etmek için yapılan tercihtir. Örneğin kişinin susaması bir ihtiyac1 doğurur. Kişi susuzluğunu gidermek için bir sıvıya ihtiyaç duyar. Bu ihtiyacını gidermek için kola veya su arasında tercih yapabilir. Kişinin bu şekilde sıv1 ihtiyacını gidermek için yapacağı tercihleri, istekleri tarafindan yönlendirilir (Odabaşı ve Barış, 2007, s. 22). İstek, beklentiden farklı bir kavramdır. Beklentiler geleceğe yönelik olurken istekler şimdiki zamana yöneliktir ve beklentilerle karşılaştırıldıklarında daha durağandırlar (Tütüncü, 2001, s. 30).

Tatmini etkileyen bir diğer unsur da algilanan performanstır. Müşteri memnuniyeti, bir ürünün, alııının beklentilerine göre değer sağlamadaki algılanan performansına bağlıdır (Kotler, Wong, Saunders ve Armstrong, 2005, s. 36). Memnuniyet ve performans arasında doğrusal bir ilişki bulunmaktadır. Satın alınan üründen elde edilen performans yüksek olduğunda; müşterinin memnuniyeti artacak, aksi durumda ise müşteri hayal kırıklığına uğrayacaktır. Tatmin olmayan müşteri ise bu tatminsizliğini yakın çevresiyle paylaşarak söz konusu ürünlerin yakın çevresi tarafından tüketilmesini önleyecektir (Öz, 2011, s. 98). Bu unsurların dışında tatmin; algılanan hizmet kalitesi, müşteri değeri, müşteri odaklılık, müşteri güveni ve kurumsal imajdan da etkilenmektedir.

Bir firmanın başarılı olması için gerekli faktörlerden biri de; rakiplerinden daha yüksek kalitede hizmet sunmak ve müşterilerin beklentilerini aşmaktır. Bu beklentiler; firmanın geçmiş deneyimleri, kulaktan kulağa iletişim ve reklamlardan oluşur. Hizmeti aldıktan sonra, müşteriler algılanan hizmeti beklenen hizmetle karşılaştırır. Algilanan hizmet beklenen hizmetin altına düşerse, müşteriler firmaya olan ilgisini kaybeder. Algilanan hizmet beklentilerini karşılar veya aşarsa, firmayı tekrar kullanmaya meyilli olurlar (Kotler, 2000, s. 206). Belirsizliği azaltmak için, müşteriler hizmet kalitesine yönelik belirli bir kanıt veya işaret ararlar. $\mathrm{Bu}$ amaçla; mekandan, insandan, ekipmandan, iletişim malzemesinden, sembollerden ve gördükleri fiyattan çıkarımlarda bulunurlar (Kotler, 2000, s. 201).

Müşteri değeri, öncelikli olarak müşterinin tatmin olmasını sağlayan, sonrasında ise tercih önceliğini belirleyen bir kavramdır (Onaran, Bulut ve Özmen, 2013, s. 41). Müşteriler çeşitli kısıtlamalar altında işlem gerçekleştirirler ve bazen işletme menfaatlerinden daha çok kişisel çıkarlarına ağırlık veren seçimler yaparlar. Tatmin olmadıklarında seçim ve tercihlerini değiştirmeleri kolaylaşır. Şirketlerin müşterileri tatmin etmek, dolayısıyla da elde tutmak için müşterilerine rakiplerinden daha fazla değer sunması gerekir. Bir işletme rakiplerin daha fazla değer sunduğunu tespit ederse, iki alternatifi vardır. Teklifin ürün, hizmet, personel veya imaj faydalarını güçlendirerek veya artırarak müşteri değerini artırmaya çalışabilir veya fiyat düşürmek, sipariş ve teslimat sürecini basitleştirmek, garanti sunmak gibi yollarla alıcı riskini azaltarak toplam müşteri maliyetini düşürebilir (Kotler, Wong, Saunders ve Armstrong, 2005, s. 465). Ancak müşteri beklentilerini karşılamayan bir mal veya hizmet, fiyatı düşük olduğunda da düşük müşteri değeriyle sonuçlanabilir (Perrault Jr., Cannon ve McCarthy, 2013, s. 18) Bu nedenle işletmenin mal, hizmet, personel veya imajını güçlendirerek rakiplerinden daha fazla değer sunması; müşterilerini elde tutması ve yeni müşteriler kazanması için daha doğru bir yol olacaktır.

Diğer bir önemli faktör de müşteri odaklllıktır. Firma personeli müşteri odaklı değilse, bu durum tüketicilerin firmayla ilgili olumsuz söylentiler yaymasına sebep olacaktır. Dolayısıyla olumsuz kulaktan kulağa pazarlama nedeniyle, firma zarara uğrayacak hatta yok olma tehlikesi yaşayabilecektir (Kotler, 2000, s. 692). İsveç'in önemli bir çokuluslu şirketi olan Tetra Pak, yenilikçi ambalajlama ve müşteri odaklllı̆̆n gücüne yönelik önemli bir örnektir. Firma, süt, meyve suyu ve diğer bozulabilir sıvı gıdaların dondurulmaksızın dağıtılmasını sağlayan bir "aseptik" paket icat etmiş ve böylece işletmelerin soğutulmuş kamyonlara ve tesislere yatırım yapmadan sütü daha geniş bir alana dağıtmalarını sağlamıştır. Süpermarketler, Tetra Pak paketli ürünlerini sıradan raflarda sergileyerek pahalı buzdolabından tasarruf etmişlerdir (Kotler, 2000, s. 196). Tetra Pak, bu şekilde müşterisi olan aracılar ve perakendecilerin ihtiyaçlarını göz önünde bulundurarak, onların ihtiyaçlarına yönelik düzenlemeler yapmıs, bu sayede memnuniyetlerini ve bağlılıklarını artırmıştır.

Mayer, Davis ve Schoorman (1995, s. 712) güveni, karşı tarafı izlemeyi ve kontrol etmeyi düşünmeden, onun eylemlerine karşı gönüllü olarak savunmasız olmak olarak tanımlamışlardır. Cook ve Wall (1980, s. 39) ise güvenin "kişinin başkalarının iyi niyetine inanmaya ne ölçüde istekli olduğu ve diğer insanların sözlerine ve eylemlerine ne kadar inandığı" anlamına geldiğini belirtmektedir. Güven 
müşterilerle ilişkilerde işletmeler tarafindan da göz önünde bulundurulan bir kavramdır. İşletmeler müşterinin tatmin olmasını sağlayarak, müşteri bağlılığını dolayısıyla da kârlılığı artırmak için müşterinin güvenini kazanmak zorundadırlar.

İşletmeler, tüketicilerin zihninde güçlü ve olumlu bir imaj oluşturmak için aktif olarak çalışırlar. Hollandalı elektronik şirketi Philips, "Bir Şeyleri İyileştirelim" etiketiyle reklam vermekte, Body Shop ve Ben \& Jerry's de sosyal problemlere destek sağlayarak dikkat çekmektedirler. Üniversiteler, müzeler ve sahne sanatları organizasyonları ise izleyicilerini ve kaynaklarını artırmak için kamusal imajlarını güçlendirmektedir (Kotler, 2000, s. 3). Kurumsal imaj, tüketicinin işletmeye yönelik algisı olduğundan tatminle de ilişkilidir. İşletmeler tüketicilerin beklentileri doğrultusunda imajlarını güçlendirmeye çalısıılar. Örneğin bazı işletmeler çevreyi koruma faaliyetlerine destek vererek, bazlları Afrika'daki çocuklar için organizasyonlar düzenleyerek, bazıları eğitici faaliyetler organize ederek tüketici nezdinde olumlu ve güçlü bir imaj oluşturmaya çalışırlar. Bu faaliyetler toplumun da beklentisi doğrultusunda gerçekleştirildiğinden, tüketicilerde tatmin duygusunun oluşmasına katkı sağlamaktadır.

\section{Literatür}

Günümüzde pek çok iletişim aracı, hedonik tüketimin bireyleri etkisi altına almasını kolaylaştırmaktadır. Bunların en önemlilerinden biri de sosyal medyadır. Markalar reklamlarında kullandıkları figürleri tüketicilere bir statü sembolü olarak yansıtarak tüketicileri alş̧verişe yönlendirmektedirler (Babacan, 2001, s. 2). Tüketiciler de satın aldıkları ürünleri veya gerçekleștirdikleri faaliyetleri sosyal medyada paylaşarak markaya veya ürüne yönelik ilgi oluşturmaktadır. Örneğin insanlar ziyaret ettikleri yerleri ve bu bölgelere özgü yiyecekleri sosyal medyada paylaşarak, o bölgeyi bilmeyen insanlarda bu deneyimi yaşama ve buralardaki lezzetleri tatma isteği uyandırmaktadırlar (Eryılmaz ve Şengül, 2016, s. 34). Böylece diğer insanlar, zorunlu bir ihtiyaç olmadığı halde, bu deneyimleri yaşamak için harcama yapmaktadırlar. Şahin ve Fırat (2018), 18 yaş üzerindeki çalışan nüfusa uyguladığı çalışmasında sosyal medya davranışlarının hedonik tüketim üzerinde etkili olduğunu tespit etmiştir. Çorumlu (2019) da yüksek öğrenim öğrencileri üzerinde yaptığı çalışmada sosyal medya reklamları ve hedonik tüketim arasında aynı yönlü anlamlı bir ilişki olduğu sonucuna ulaşmıştır. Yalın (2019), üniversite öğrencileri üzerine yaptığı çalışmada, tüketicilerin hedonik tüketim davranışlarının sosyal medyada geçirilen süreye göre farklılıklar gösterdiğini ve ürünlerin sosyal medya paylaşım platformlarında daha ucuz olduğunu düşünenler, sosyal medyada ürün tanıtımı yapan reklamları izleyenler, sosyal medyada gördüğü bir ürünü almak için alışverişe çıkanlar, sosyal medyayı alışveriş yapmak amacıyla kullananlar ve sosyal medyayı ürün ve hizmetler hakkında bilgi toplamak amacıyla kullananlar ile hedonik tüketim davranışları arasında anlamlı bir ilişki olduğunu tespit etmiştir. Aydın (2019), otomobil kullananlar üzerine yaptığı çalışmada sosyal medyanın otomobil kullanıcılarının hedonik tüketim davranışları üzerinde etkisi olduğu çıkarımında bulunmaktadır. Bu bilgiler ışığında aşağıdaki hipotez oluşturulmuştur;

H1: Bireylerin sosyal medya kullanımı ile hedonik tüketim davranışları arasında pozitif yönlü bir ilişki vardir.

Ürünleri imaj ve prestij kaygisı ile tüketen, tüketimden haz almayı ön planda tutan tüketiciler hedonik faktörleri dikkate alarak tercihler yapmaktadırlar. Bu tüketiciler duygusal hazları giderme, sosyalleşme ve statü arayışı gibi amaçlarla mal ve hizmetlere yönelmekte ve bu amaçlar doğrultusunda tercihlerini gerçekleştirmektedirler (Baş ve Samsunlu, 2015, s. 33). Batra ve Ahtola (1991) tüketici tutumlarının hedonik ve faydacı güdülerden kaynaklandığını belirtmektedir. Tüketicilerin markalara ve ürünlere karşı tutumlarının geliştirilmesinde çok karmaşık süreçler ve değişik faktörler etkili olmaktadır. Hedonik ve faydac1 güdüler bu faktörlerin en önemlilerindendir (Voss, Spangenberg ve Grohmann, 2003). Güven (2018), üniversite öğrencilerinin cep telefonu kullanımları üzerine yaptığı uygulamada hedonik değerlerin tutum ve tatmin üzerinde pozitif yönlü bir etkiye sahip olduğunu tespit etmiştir. Doğrul ve Aksay (2017), alışveriş merkezinden alışveriş yapan tüketiciler üzerinde gerçekleştirdikleri çalışmada eğlence, keşfetme ve sosyal statü ihtiyaçları karşılanan tüketicilerin alışverişten tatmin oldukları sonucuna ulaşmışardır. Demirci Orel ve Kaçmaz (2019), Y ve Z kuşakları üzerinde yaptıkları çalışmada Z kuşağının algıladığı hedonik değerin tatminleri üzerinde anlamlı bir etkisi olduğunu tespit etmiştir. Çoban ve Keskin (2018) hedonik duygular içeren motivasyon unsurlarının e-tatmine etkisini araştırdıkları çalışmalarında hedonik tüketim boyutları olan maddi değer, başkalarına yardım, yenilik ve sosyalleşme arayışının e-tatminin önemli açıklayıcıları olduğu sonucuna varmışlardır. Bu bilgiler ışı̆̆ında aşağıdaki hipotezler oluşturulmuştur;

H2: Bireylerin hedonik tüketim davranışları, tüketime yönelik tutumları üzerinde pozitif etkiye sahiptir. 
H3: Bireylerin hedonik tüketim davranışları, tatminleri üzerinde pozitif etkiye sahiptir.

\section{Yöntem}

Araştırmanın amacı, önemi, yöntemi, hipotezleri, veri toplama araçları ve yapılan analizler bu bölümde bulunmaktadır.

\section{Araştırmanın Amacı ve Önemi}

Araştırmanın temel amacı, internetten alısveriş yapan tüketicilerin sosyal medya kullanımlarının hedonik tüketim üzerindeki etkisini ve hedonik davranışlarının tutumları ve tatmin düzeyleri üzerindeki etkisini belirlemektedir. İnternet kullanımının hızla yayılması ve sağladığı kolaylıklar nedeniyle tüketicilerin internet üzerinden alısverişi yoğun bir şekilde kullanması, işletmeleri de bu alanda etkili pazarlama çalışmaları yapmaya zorlamaktadır. İşletmeler internet üzerinden satışlarını desteklemek amacıyla tüketicilere fiyat, kalite ve kolaylık sunmanın yanında alısveriş sürecini de onlar için eğlenceli hale getirmeye odaklanmaktadırlar. Bunun için sitelerini bu amaca uygun dizayn etmekte, tüketicilerin haz duymasını sağlayacak faaliyetler düzenlemekte, sosyal medya kanalları aracilğ̆ıla mal ve hizmetler hakkında bilgiler vermekte, ürün tanıtımları yapmakta, bunun için; sosyal medya fenomenleri ve tanınmış kişileri kullanmaktadırlar. $\mathrm{Bu}$ faaliyetlerle tüketicilerin ürünlerden ve alısveriş sürecinden tatmin olmasını sağlayarak işletmeye veya markaya yönelik olumlu tutum geliştirmelerini sağlamayı amaçlamaktadırlar. Bu araştırma tüketicilerin sosyal medya kullanımının haz odaklı alışverişleri üzerindeki etkisini ve bu amaçla gerçekleştirdikleri alışverişlerin tatmin düzeyleri ve işletmeye yönelik tutumları üzerindeki etkisini belirlemesi açısından önem taşımaktadır.

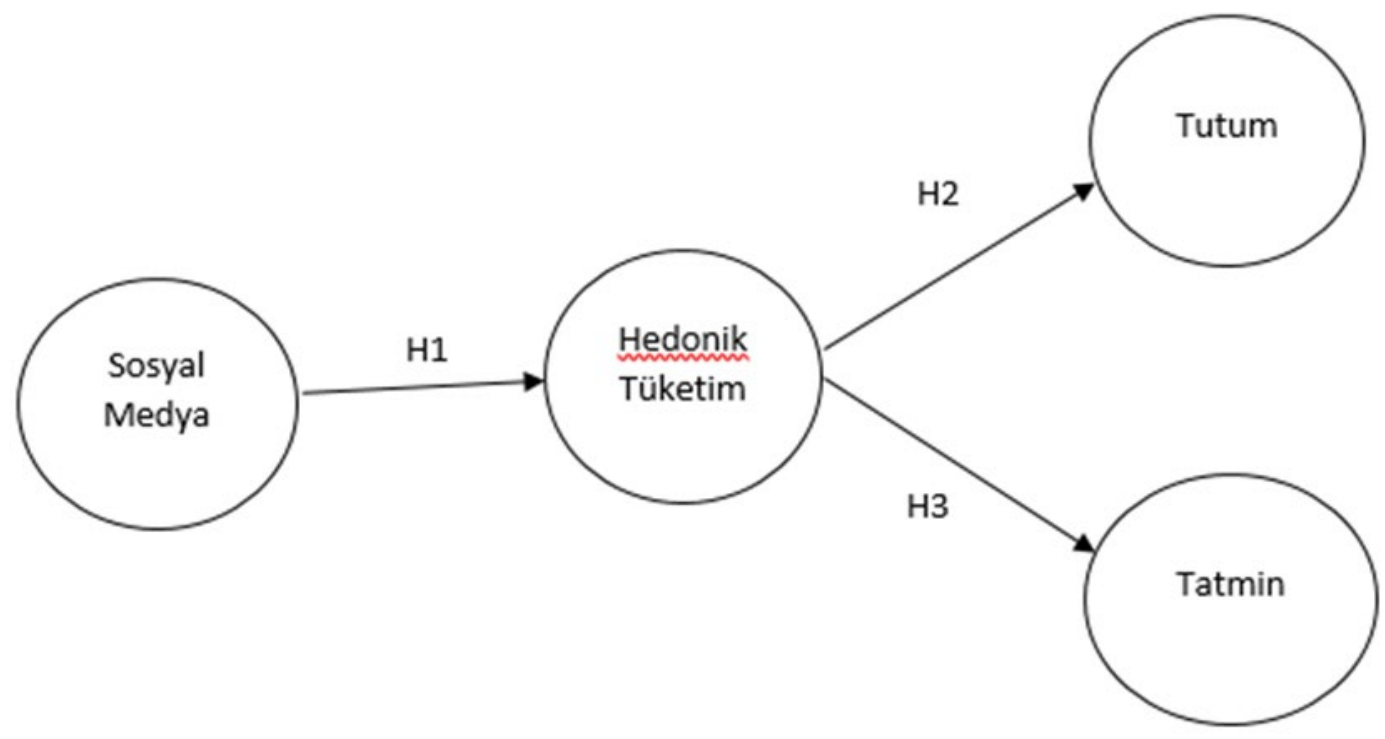

Şekil 1. Arastrmann Modeli vardır.

H1: Bireylerin sosyal medya kullanımı ile hedonik tüketim davranışları arasında pozitif yönlü bir ilişki

H2: Bireylerin hedonik tüketim davranışları, tüketime yönelik tutumları üzerinde pozitif etkiye sahiptir.

H3: Bireylerin hedonik tüketim davranışları, tatminleri üzerinde pozitif etkiye sahiptir.

\section{Evren - Örneklem}

Araştırmanın evrenini Sakarya ilinde ikamet eden ve internetten alışveriş yapan tüketiciler oluşturmaktadır. Araştırmada en az maliyetle en kısa zamanda bilgi toplanması amaçlandığında tesadüfi olmayan örnekleme yöntemlerinden kolayda örnekleme yöntemi kullanılmıştır. Sakarya ilinin toplam nüfusu 1,03 milyondur. Buradan hareketle araştırmanın evreninin 1,03 milyon olduğunu söyleyebiliriz. Araştırmanın örneklemini ise Sakarya ilinde ikamet eden 391 tüketici oluşturmaktadır. 


\section{Veri Toplama Araçları}

Araştırmada veri toplama yöntemi olarak anket uygulaması kullanılmışır. Anket uygulaması her bir katılımciya yüz yüze anket uygulanmas1 şeklinde 30.09.2019-30.10.2019 tarihleri arasında gerçekleştirilmiştir. Anketin ilk kısmı katılımcılara ait yaş, cinsiyet, medeni durum, meslek, eğitim durumu ve gelir durumunu içeren demografik sorulardan oluşmaktadır. İkinci kısımda ise katılımcıların sosyal medya kullanımlarını, hedonik alışveriş davranışlarını, tutumlarını ve tatmin düzeylerini belirlemeye yönelik sorular bulunmaktadır. Ankette katılımcıların sosyal medya kullanım davranışını ölçmeye yönelik 26 soru bulunmaktadır. Bu sorular Leung (2001) tarafindan geliştirilen ölçekten uyarlanmıştır. Hedonik davranışları belirlemeye yönelik sorular ise Arnold ve Reynolds (2003) tarafindan geliştirilen ölçekten uyarlanmıştır ve 23 adettir. Katılımcıların alışveriş sitelerine yönelik tutumlarını belirlemek için kullanılan sorular Shiv, Edell ve Payne (1997) tarafından geliştirilen ve Yağcı ve İlarslan'ın (2010) çalşsmasında kullandığı sorulardan uyarlanmıştır. Ankette tutumu belirlemeye yönelik 4 adet, katılımcıların tatmin düzeyini belirlemeye yönelik 5 adet soru bulunmaktadır. Bu sorular, Topçu'nun (2017), Kim (2009) ve Alfalla-Luque, Marin-Garcia ve Medina-Lopez'in (2014) çalışmalarından aldığı ve çalışmasında kullandığı sorulardan uyarlanmıştır. Elde edilen veriler AMOS 24 ve SPSS 21 programlarında analiz edilmiştir.

\section{Verilerin Analizi}

\section{Güvenilirlik ve Faktör Analizi}

Ölçeklerin güvenilirliklerini ölçmek amacıyla öncelikle ölçeklere güvenilirlik analizi yapıllmıştır. Yapılan analizler sonucunda elde edilen Cronbach's Alfa kat sayıları sırasıyla sosyal medya davranışları ölçeğinin 0,93 , hedonik tüketim davranışları ölçeğinin 0,90 , tutum ölçeği 0,913 ve tatmin ölçeği 0,908 olarak tespit edilmiştir. Ölçeklerin örneklemle uyum gösterip göstermediğini incelemek amaciyla faktör analizi yapılmıştır (Turanlı, Taşpınar Cengiz ve Bozkır, 2012, s. 49). Faktör yükü 0,50 altında olan değişkenler dikkate alınmamıştır. $\mathrm{Bu}$ doğrultuda hedonik tüketim davranışları ölçeğindeki "Alışveriş yapmayı kışkırtıcı bulurum" ifadesi ve sosyal medya davranışları ölçeğindeki "Sosyal medyada zaman öldürürüm" ve "Sosyal medya beni baskılardan ve sorumluluklardan uzaklaştırır" ifadeleri faktör yükleri 0,50'nin altında olduğu için analizden çıarılmıştır. Faktör analizi sonucunda hedonik davranış ölçeği; macera, değer elde etme, başkaları için alşveriş, fikir edinme, sosyalleşme ve rahatlama olmak üzere 6 boyuttan oluşmakta ve toplam varyansın \%64,47'sini açıklamakta, sosyal medya davranış ölçeği; rahatlama ve eğlence, sosyalleşme, moda, etkileşim ve dahil olma ve kaçış olmak üzere 5 boyuttan oluşmakta ve toplam varyansin \%65,45'ini açılklamakta, tutum ve tatmin ölçekleri ise birer boyuttan oluşmakta ve toplam varyansın sırasıyla \%65,920’sini ve \%73,077’ini açıklamaktadırlar. Ayrıca hedonik tüketim ölçeğinin KMO değeri 0,873, Barlett Küresellik testi: 4709,564 ve p<0,000; sosyal medya davranışları ölçeğinin KMO: 0,919, Barlett: 6244,365 ve p<0,000; tutum ölçeğinin KMO: 0,921, Barlett: 1697,068 ve p<0,000; tatmin ölçeğinin KMO: 0,887, Barlett: 1259,920 ve $\mathrm{p}<0,000$ olarak bulunmuştur.

Araştırma sosyal medyanın hedonik tüketim üzerindeki etkisini ve hedonik tüketimin tutum ve tatmin üzerindeki etkisini araştırmayı amaçladığından sosyal medya ve hedonik tüketimin her bir boyutunu tek tek analize sokmak yerine bu değişkenler bir bütün halinde birer boyut olarak analize dahil edildi. Bunu gerçekleştirmek için, sosyal medya davranışları ölçeğinin her bir boyutunun ortalaması alınmış ve her boyut tek bir madde haline dönüştürülmüştür. Aynı işlem hedonik tüketim ölçeği için de gerçekleştirilmiştir. Bu şekilde sosyal medya davranışları ölçeği 5 , hedonik tüketim ölçeği 6 maddeden ibaret hale gelmiştir ve sırasıyla toplam varyansın $\% 53,983$ ve $\% 58,845$ 'ini açılamaktadırlar. Bu şekilde yapılan analizler neticesinde sosyal medya ve hedonik tüketim ölçeklerinin cronbach's alpha katsayıları sırasılyla 0,885 ve 0,858 olarak tespit edilmiştir. Sosyal medya davranışları ölçeğinin KMO değeri 0,811, Barlett Küresellik testi: 519,248 ve p<0,000; hedonik tüketim ölçeğinin KMO değeri 0,841, Barlett Küresellik testi: 1071,766 ve $\mathrm{p}<0,000$ olarak tespit edilmiştir. Yapılan analizler neticesinde elde edilen sonuçlar Tablo 2'de gösterilmiştir. 
Tablo 1. Faktör Analizi Sonuclar

\begin{tabular}{|c|c|c|c|}
\hline Değişkenler & $\begin{array}{l}\text { Faktör } \\
\text { Yükleri }\end{array}$ & $\begin{array}{l}\text { Varyans } \\
\text { Yüzdesi }\end{array}$ & $\begin{array}{c}\ddot{O} z \\
\text { Değer }\end{array}$ \\
\hline Hedonik Tüketim (Cronbach Alpha: 0,858) & & 58,845 & 3,634 \\
\hline Macera olarak alışveriş & 0,784 & & \\
\hline Değer elde etmek için alışveriş & 0,675 & & \\
\hline Başkaları için alışveriş & 0,696 & & \\
\hline Fikir edinmek için alışveriş & 0,829 & & \\
\hline Sosyalleşmek için alışveriş & 0,816 & & \\
\hline Rahatlamak için alışveriş & 0,821 & & \\
\hline Sosyal Medya Kullanımı (Cronbach Alpha: 0,885) & & 53,983 & 2,937 \\
\hline Rahatlama ve eğlence & 0,789 & & \\
\hline Sosyalleşme & 0,774 & & \\
\hline Moda & 0,738 & & \\
\hline Etkileşim & 0,696 & & \\
\hline Dahil olma ve kaçış & 0,667 & & \\
\hline Tutum (Cronbach Alpha: 0,913) & & 65,920 & 4,614 \\
\hline $\mathrm{Bu}$ alı̧veriş sitesinden alışveriş etmek doğru bir karardır. & 0,788 & & \\
\hline $\mathrm{Bu}$ alışveriş sitesi tatmin edicidir. & 0,838 & & \\
\hline $\mathrm{Bu}$ alışveriş sitesinin pek çok faydalı özelliği var. & 0,843 & & \\
\hline $\mathrm{Bu}$ alışveriş sitesine ilişkin olumlu düşüncelerim var. & 0,826 & & \\
\hline Tatmin (Cronbach Alpha: 0,908 ) & & 73,077 & 3,654 \\
\hline $\mathrm{Bu}$ alışveriş sitesinden yaptığım alışverişlerde verdiğim paranın karşılığını aldığımı düşünürüm. & 0,853 & & \\
\hline $\mathrm{Bu}$ alışveriş sitesinden satın aldığım ürünlerin kalitesinden memnunum. & 0,882 & & \\
\hline $\mathrm{Bu}$ alışverişs sitesinde satılan ürünlerin benim nezdimdeki itibarı yüksektir. & 0,857 & & \\
\hline $\mathrm{Bu}$ alışveriş sitesi ihtiyaçlarımı zamanında temin eder. & 0,847 & & \\
\hline $\mathrm{Bu}$ alışveriş sitesinin sunduğu ürün ve hizmetlerden memnunum. & 0,834 & & \\
\hline
\end{tabular}

\section{Bulgular}

\section{Demografik Bulgular}

Demografik değerlere ilişkin veriler Tablo 2'de gösterilmiştir.

Tablo 2. Katullmclarn Demografik Özellikleri

\begin{tabular}{|c|c|c|c|c|c|c|c|}
\hline \multicolumn{2}{|c|}{ Değişken } & Frekans & Yüzde & \multicolumn{2}{|c|}{ Değişken } & Frekans & Yüzde \\
\hline \multirow{3}{*}{ Cinsiyet } & Kadın & 161 & 41,2 & \multirow{3}{*}{$\begin{array}{l}\text { Medeni } \\
\text { Durum }\end{array}$} & $\overline{\text { Evli }}$ & 79 & 20,2 \\
\hline & Erkek & 230 & 58,8 & & Bekar & 312 & 79,8 \\
\hline & Toplam & 391 & 100,0 & & Toplam & 100 & 100,0 \\
\hline \multirow{5}{*}{ Yaş } & 17 ve alt1 & 38 & 9,7 & \multirow{5}{*}{$\begin{array}{l}\text { Eğitim } \\
\text { Durumu }\end{array}$} & İlköğretim & 6 & 1,5 \\
\hline & $18-28$ & 248 & 63,4 & & Ortaöğretim & 66 & 16,9 \\
\hline & $29-39$ & 83 & 21,2 & & Önlisans/Lisans & 274 & 70,1 \\
\hline & 40 ve üstü & 22 & 5,7 & & Lisansüstü & 45 & 11,5 \\
\hline & Toplam & 391 & 100,0 & & Toplam & 391 & 100,0 \\
\hline \multirow{7}{*}{ Gelir Durumu } & 1600 ve alt1 & 238 & 60,9 & \multirow{7}{*}{$\begin{array}{l}\text { Serbest } \\
\text { Meslek }\end{array}$} & Serbest Meslek & 17 & 4,3 \\
\hline & $1601-3200$ & 43 & 11,0 & & Esnaf & 15 & 3,8 \\
\hline & $3201-4800$ & 70 & 17,9 & & Memur & 97 & 24,8 \\
\hline & 4801 ve üstü & 40 & 10,2 & & İşçi & 17 & 4,3 \\
\hline & \multirow[t]{3}{*}{ Toplam } & 391 & 100,0 & & Öğrenci & 219 & 56 \\
\hline & & & & & Diğger & 26 & 6,8 \\
\hline & & & & & Toplam & 391 & 100,0 \\
\hline
\end{tabular}

Katılımcıların \%41,2'si kadın, \%58,8’i ise erkektir. Katılımcıların çoğu 18-28 yaş arasındadır ve önemli bir bölümü 1600 TL ve altında gelire sahiptir. Bekar olanların oranı $(\% 79,8)$ evli olanlardan $(\% 20,2)$ hayli yüksektir. Çoğunluğu ön lisans ve lisans seviyesindeki $(\% 70,1)$ öğrenciler $(\% 56)$ oluşturmaktadır. 


\section{Araştırma Modelinin Yapısal Eşitlik Uygunluğunun Değerlendirilmesi ve Sonuçları}

Sosyal medyanın hedonik tüketim davranışı üzerindeki etkisi ve hedonik tüketimin tutum ve tatmin üzerindeki etkisi ile ilgili modelin uygunluğunu değerlendirmek için ki-kare istatistiği RMSEA(Ortalama hata karekök yaklaşımı) ve GFI (Uyum iyiliği indeksi) dikkate alınmıştır. Ki- karenin üçten küçük olduğu ve anlamlı olmadığı durumlar modelin uyumunu göstermektedir. Ancak bazı yazarlar ki-kare 3’ten küçük ise modelin anlamlı bile olsa kabul edilebilir olduğunu savunmaktadırlar (Meydan ve Şeşen, 2011). RMSEA, 0 ve 1 arasında değerler almaktadır ve RMSEA'nın 0,05 ve daha küçük değerler alması modelin iyi uyum gösterdiği, 0,08'e kadar değerler alması kabul edilebilir uyum gösterdiği, 0,08'den büyük değerler alması ise kötü uyum gösterdiği anlamına gelmektedir. 0 ve 1 arasında değerler alan GFI değerinin ise 0,95 ve üzerinde değerler almas1 iyi uyum, 0,90 ve 0,94 arası değerler alması kabul edilebilir uyumun göstergesidir (Şimşek, 2007, s. 48). Yapılan analizler sonucunda ulaşılan değerler modelin kabul edilebilir uyum sınırları içerisinde olduğunu ve modelin uygunluğunu göstermektedir.

Tablo 3. Yapısal Eşitlik Değerlendirme Tablosu

\begin{tabular}{lcccccc}
\hline & $\boldsymbol{X} 2$ & $\boldsymbol{D f}$ & $\boldsymbol{X} 2 / \boldsymbol{d f}$ & $\boldsymbol{G F I}$ & $\boldsymbol{C F I}$ & $\boldsymbol{R} \boldsymbol{M S E A}$ \\
\hline Uyum Değerleri & 505,732 & 221 & 2,288 & 0,903 & 0,950 & 0,056 \\
Iyi Uyum Değerleri & & & $\leq 3$ & $\geq 90$ & $\geq 0,97$ & $\leq 0,05$ \\
Kabul Edilebilir Uyum Değerleri & & & $\leq 4-5$ & $\geq 85$ & $\geq 0,95$ & $0,05-0,08$ \\
\hline
\end{tabular}

Uyum değerlerinden GFI: 0,903, CFI: 0,950, NFI: 0,908, IFI: 0,946, RFI: 0,905 ve TLI: 0,938 olarak bulunmuş ve hipotez testi sonuçları aşağıdaki tabloda gösterilmiştir.

Tablo 4. Hipotez Tablosu

\begin{tabular}{|c|c|c|c|c|c|}
\hline & $X 2$ & Estimate & S.E. & $p$ & Durum \\
\hline H1 & $\begin{array}{c}\text { Sosyal Medya } \rightarrow \text { Hedonik } \\
\text { Tüketim }\end{array}$ & ,965 &, 104 &, $000^{*}$ & Kabul \\
\hline $\mathrm{H} 2$ & Hedonik Tüketim $\rightarrow$ Tutum & ,313 & ,049 &, $000^{*}$ & Kabul \\
\hline $\mathrm{H} 3$ & Hedonik Tüketim $\rightarrow$ Tatmin & ,270 & 049 &, $000^{*}$ & Kabul \\
\hline
\end{tabular}

Yapısal modelde temelde üç hipotez incelenmiştir. H1: Bireylerin sosyal medya kullanımı ile hedonik tüketim davranışları arasında pozitif yönlü bir ilişki vardır. H2: Bireylerin hedonik tüketim davranışları, tüketime yönelik tutumları üzerinde pozitif etkiye sahiptir. H3: Bireylerin hedonik tüketim davranışları, tatminleri üzerinde pozitif etkiye sahiptir. Oluşturulan yapısal modelde elde edilen sonuçlara göre modelin uyumlu olduğu ve model uyum indeks değerlerinin istenilen sınırlarda olduğu gözlemlenmiştir. Analizler sonucunda sosyal medya ve hedonik tüketim arasındaki yol kat sayısı istatistiksel olarak anlamlı bulunmuştur. $(\beta=0,965, p=0,000)$. Böylece $\mathrm{H} 1$ hipotezi doğrulanmıştır. Hedonik tüketim ve tüketici tutumu arasındaki yol kat sayısı $(\beta=0,313, \mathrm{p}=0,000)$ ile hedonik tüketim ve tatmin arasındaki yol katsayıs1 $\mathrm{da}(\beta=0,270, \mathrm{p}=0,000)$ anlamlı bulunmuştur. Bu sonuçlar $\mathrm{H} 2$ ve H3 hipotezlerinin de doğrulandığını göstermektedir.

\section{Tartışma, Sonuç ve Öneriler}

Günümüzde teknolojinin gelişmesine paralel olarak internetin de gelişmesi ve geniş bir kullanım alanı bulması, işletmeler arasındaki rekabetin boyutunu da genişletmiştir. İşletmeler müşteri ilişkileri geliştirmek, pazar hacmini artırmak, tutundurma faaliyetleri gerçekleştirmek gibi amaçlarla interneti kullanmaktadırlar. İşletmelerin internet aracilğ̆yla müşterilerle ilişki kurduğu ve pazarlama faaliyetleri gerçekleştirdiği kanallardan biri de sosyal medyadır. Tüketiciler sosyal medya kanallarını yoğun olarak kullanmakta ve sosyal medyadan edindikleri bilgilere önem vermektedirler. Dolayısıyla sosyal medya; tüketicilerin alısveriş alışkanlıklarını etkilemekte, işletmelere karşı tutumları ve tatmin düzeyleri üzerinde belirleyici olabilmektedir. Bu nedenle sosyal medya günümüzde işletmeler tarafindan gittikçe daha fazla kullanılmaya başlanmışır. Bu çalışmada da internet üzerinden alışveriş yapan tüketicilerin sosyal medya kullanım alışkanlıklarından etkilenen hedonik tüketim davranışlarının tutumları ve tatmin düzeyleri üzerindeki etkisi araştırılmıştır. Bu amaçla tüketicilere anket uygulanmış ve yapılan analizler neticesinde tüketicilerin sosyal medya kullanım alıskanlıklarının hedonik tüketim davranışları üzerinde ve hedonik tüketim davranışlarının tutum ve tatmin düzeyleri üzerinde olumlu bir etkisi olduğu sonucuna ulaşılmıştır.

Yapılan araştırmanının sonuçları incelendiğinde tüketicilerin sosyal medya kullanım alışkanlıklarının hedonik tüketim davranışları üzerinde olumlu bir etkisi olduğu görülmektedir. Bu doğrultuda H1 hipotezi 
desteklenmektedir. Bu sonuçlar önceki çalışmaların sonuçlarıyla da uyumludur. Şahin ve Fırat(2018) yaptıkları çalışmada sosyal medyanın hedonik tüketim davranışları üzerinde olumlu etkisi olduğu sonucuna ulaşmışlardır. Günümüzde tüketiciler gerçekleştirdikleri birçok faaliyeti sosyal medyada paylaşmakta ve faaliyeti gerçekleştirdikleri işletmeleri de etiketleyerek reklamını yapmaktadırlar. Bu paylaşımlar farklı insanları etkileyerek onlarında aynı deneyimleri yaşamayı arzulamalarına sebep olmaktadır. Bu nedenle işletmeler, müşterileri ile etkileşim kurarak onların hedonik güdülerini harekete geçirmek ve bu yöndeki beklentilerine cevap vermek için sosyal medya platformlarını etkili bir şekilde kullanmalıdırlar.

Yapılan analizler sonucunda internet üzerinden alşsveriş yapan tüketicilerin hedonik güdülerinin tutumları ve tatmin düzeyleri üzerinde etkili olduğu sonucuna ulaşılmıştır. Bu sonuçlar $\mathrm{H} 2$ ve $\mathrm{H} 3$ hipotezlerini doğrulamaktadır. Bu sonuçlar literatürle de uyumludur. Batra ve Ahtola(1991) ile Voss, Spangenberg ve Grohmann(2003) hedonik ve faydacı güdülerin tüketici tutumlarının önemli belirleyicilerinden olduğunu belirtmektedir. Hedonik değerlerin müşteri tatmininin temelinde yatan sebepler üzerinde de olumlu etkisi vardır(Güven, 2018). Hedonik motivasyonlar olan bağlanma yeri ve sosyal statü tüketicilerin tatmin düzeyleri üzerinde pozitif bir etkiye sahiptir(Demirci Orel ve Kaçmaz, 2019). Hedonik tüketiciler ürün ve hizmetlerin sahip olduğu prestijden etkilenmekte ve tüketimi bu amaçla gerçekleştirmektedir. Hedonik faktörlerin kendilerine kazandırdıklarını ön planda tutan hedonik tüketiciler tercihlerini de bu doğrultuda gerçekleştirmektedir. Bu nedenle işletmelerin; internet sitesinin çekiciliği, reklamların etkileyiciliği, ürünün prestijinin ön plana çıkarılması, ürünün sosyal statü sembolü olması vb. özellikleri ön plana çıkararak, tüketicilerin hedonik güdülerine hitap edecek pazarlama faaliyetleri gerçekleştirmesi gerekmektedir.

Araştırmanın; sosyal medya, hedonik tüketim, tüketici tutumu ve tatmin ile ilgili literatüre önemli katkılar sağlayacağı düşünülmektedir. Araştırmanın sadece bir şehir merkeziyle sınırlı olması önemli bir kısıttır. Gelecekteki çalışmaların daha geniş bir alanda, daha farklı tüketici grupları ve daha fazla katılımcı üzerinde yapılması ve sonuçlarının mevcut çalışmalarla karşılaştırılması literatüre önemli katkılar sağlayacaktır.

\section{Etik Beyan}

"Sosyal Medya ve Hedonik Tüketimin Tüketici Tutumu ve Tatmin Üzerindeki Etkisi" başlıklı çalışmanın yazım sürecinde bilimsel kurallara, etik ve alıntı kurallarına uyulmuş; toplanan veriler üzerinde herhangi bir tahrifat yapilmamış ve bu çalışma herhangi başka bir akademik yayın ortamına değerlendirme için gönderilmemiş̧ir. Bu araştırmanın verileri 01.01.2020 tarihinden önce toplandığ1 ve makalenin süreci 2020 yılında başladığından etik kurul kararı zorunluluğu taşımamaktadır.

\section{Kaynakça}

Adomaviciute, K. (2013). Relationship between utilitarian and hedonic consumer behavior and socially responsible consumption. Journal of Economics and Managment, 18(4), 754-760.

Alfalla-Luque, R., Marin-Garcia, J. A. ve Medina-Lopez, C. (2014), An analysis of the direct and mediated effects of employee commitment and supply chain integration on organisational performance. International Journal of Production Economics, 162(C), 242-257.

Akgül, D. ve Varinli, İ. (2017). Hedonik (hazcı) tüketimin özel günlerdeki alsşveriş kültürü üzerindeki etkisi ve ülkelerarası karşılaştırmalı bir araştırma. U.Ü. Sosyal Bilimler Enstitüsü Dergisi, 10(2), 1-36.

Altındal, M. (2013). Dijital Pazarlamada Marka Yönetimi ve Sosyal Medyanın Etkileri. Akademik Bilisim 2013 - XV . Akademik. Bilisim Konferansı Bildirileri. 23-25 Ocak 2013 - Akdeniz Üniversitesi, Antalya, 1087-1901.

Arnold M. J. ve Reynolds, K. E. (2003). "Hedonic shoping motivations, Journal of Retailing, 79(2), 77-95.

Arslan, B. (2016). Etnik kökenin hedonik tüketime etkisi: türkiye'de yaşayan farklı etnik kimliğe sahip tüketiciler üzerine bir araştırma. Akademik Bakış Dergisi, 53, 272-285.

Avcı, İ. ve Yıldız, E. (2019). Fenomenlerin güvenilirlik, çekicilik ve uzmanlık özelliklerinin marka tutumu, satın alma niyeti ve elektronik kulaktan kulağa pazarlama üzerindeki etkileri: instagram örneği. Kocaeli Üniversitesi Sosyal Bilimler Dergisi, 38, 85-107.

Aydın, S. (2019). Otomobil terciblerinde marka imajı ve sosyal medyann bedonik tüketim davramssina etkileri (Yükse Lisans Tezi). İstanbul Üniversitesi, Sosyal Bilimler Enstitüsü, İstanbul.

Aytan, C. ve Telci, E. E. (2014). Markaların sosyal medya kullanımının tüketici davranışı üzerindeki etkileri. The Turkish Online Journal of Design, Art and Communication - TOJDAC, 4(4), 1-15.

Babacan, M. (2001), Hedonik Tüketim ve Özel Günler Alı̧verişlerine Yansıması. 6. Ulusal Pazarlama Kongresi. Erzurum, 97-106.

Babin, B. J., Darden, W. R. ve Griffin, M. (1994). Work and/or fun: measuring hedonic and utilitarian shopping value. Journal of Consumer Research, 20(4), 644-656. 
Bakırtaş, H. ve Uslu Divanoğlu, S. (2013). The effect of hedonic shopping motivation on consumer satisfaction and consumer loyalty. International Journal of Asian Social Science, 3(7), 1522-1534.

Baş, M. ve Samsunlu, G. (2015). Starbucks coffee tüketicilerinin demografik özelliklerinden biri olan cinsiyete göre hedonik tüketim nedenlerinden etkilenme tutumlarının belirlenmesi. Gazi Üniversitesi İktisadi ve İdari Bilimler Fakültesi Dergisi, 17(1), 14-34.

Batra, R. ve Ahtola, O. T. (1991). Measuring the hedonic and utilitarian sources of consumer attitudes. Marketing Letters, 2(2), 159-170.

Boyd, D. M., ve Ellison, N. B. (2007). Social network sites: definition, history, and scholarship. Journal of ComputerMediated Communication, 13(1), 210-230.

Bulut, E. (2012). Pazarlama iletisiminde yeni yaklaşımlar kapsaminda sosyal medya uygulamalar ve etkili kampanya örnekleri (Yüksek Lisans Tezi). İstanbul Kültür Üniversitesi, Sosyal Bilimler Enstitüsü, İstanbul.

Coley, A. (2002). Affective and Cognitive Processes Involved in Impulse Buying (MSc Study, BSFCS). The University of Georgia, Athens, Georgia: USA.

Cook, J. ve Wall, T. (1980). New work attitude measures of trust, organizational commitment, and personal need nonfulfillment. Journal of Occupational Psychology, 53, 39-52.

Cooke, M. ve Buckley, N. (2008). Web 2.0, social networks and the future of market research. International Journal of Market Research, 50(2), 267-292.

Çalışır, G. (2015). Kişilerarası iletişimde kullanılan bir araç olarak sosyal medya: gümüşhane üniversitesi iletişim fakültesi öğrencilerine yönelik bir araştırma. E-Journal of New World Sciences Academy, 10(3), 115-144.

Çoban, S. ve Keskin, S. (2018). "İnternet bankacıllğıında hedonik motivasyon unsurları, e-tatmin ve e-bağlllık etkileşimi: Nevşehir ili örneği. Erciyes Üniversitesi İktisadi ve İdari Bilimler Fakültesi Dergisi, 52, 93-114.

Çorumlu, B. (2019). Sosyal medya reklamlarmm bedonik tüketim ve plansız satın alma üzerine etkisi (Yüksek Lisans Tezi). Selçuk Üniversitesi, Sosyal Bilimler Enstitüsü, Konya.

Dabholkar, P. A. (1994). Incorporating choice into an attitudinal framework: analyzing models of mental comparison processes. Journal of Consumer Research, $21(1), 100-118$.

Demirci Orel, F. ve Kaçmaz, Ö. (2019). Hedonik ve faydacı değerlerin müşteri tatminine etkilerinin y ve z kuşakları açısından incelenmesi. C.Ü. Sosyal Bilimler Enstitüsü Dergisi, 28(3), 277-297.

Dhar, R. ve Wertenbroch, K. (2000). Consumer choice between hedonic and utilitarian goods. Journal Of Marketing Research, 37(1), 60-71.

Doğrul, Ü. ve Aksay, N. (2017). Alış veriş merkezlerinden elde edilen tatmini etkileyen hedonik ve faydacı güdülerin incelenmesi: Mersin İli Örneği, 3. Uluslararası Politik, Ekonomik ve Sosyal Araştırmalar Kongresi. Ankara, 9-11 November, ss. 121-122,

Eryılmaz, B. ve Şengül, S. (2016). Sosyal medyada paylaşılan yöresel yemek fotoğraflarının turistlerin seyahat tercihleri üzerindeki etkisi. Uluslararası Türk Dünyası Turižm Arastırmalar Dergisi, 1(1), 32-42.

Fromm, E. (2008). To have or to be?. London: Continuum Publishing.

Güven, E. (2018). Tüketicilerin tatmin ve tutumlarının belirlenmesinde hedonik ve faydacı değerlerin rolü: üniversite öğrencilerinin cep telefonu kullanımları üzerine bir uygulama. Dumlupınar Üniversitesi Sosyal Bilimler Dergisi, 55, 157-173.

Hacıefendioğlu, Ş. (2014). Sosyal medyanın marka bağlılığına etkisi üzerine bir araştırma. Kocaeli Üniversitesi Sosyal Bilimler Dergisi, 28, 59-70.

Haddock, G. ve Maio, G. R. (2008). Attitudes: Content, structure and functions. Hewstone, M., Stroebe, W. ve Jonas, K., Introduction to social psychology: A European perspective (BPS textbooks in psychology) içinde (112-133), 4. Edition, New Jersey: Blackwell Publishing.

Hanzaee, K. H. ve Irani, N. (2011). The effects of Iranian consumers' buying tendencies on utilitarian and hedonic shopping value. African Journal of Business Management, 5(17), 7449-7460.

Hawkins, D. I. ve Mothersbaugh, D. L. (2010). Consumer behavior: Building marketing strategy, New York: McGraw-Hill.

Hirschman, E. C. ve Holbrook, M. B. (1982). Hedonic consumption; emerging concepts, methods and propositions. Journal of Marketing, 46(3), 92-101.

Hopkinson, G. C. ve Pujari, D. (1999), A factor analytic study of the sources of meaning in hedonic consumption. Europen Journal of Marketing, 33(3/4), 273-294.

Hoyer, W. D. ve MacInnis, D. J. (2008). Consumer behavior. 5. Edition, U.S.A.: South Western College.

Hudson, L. A. ve Murray, J. B. (1986). Methodological limitations of the hedonic consumption paradigm and a possible alternative: A subjectivist approch. Advances in Consumer Research, 13, 343-348.

İslamoğlu, A. H. (2003). Tüketici davranısları. İstanbul: Beta Basım Yayım.

Kaplan, A. M. ve Haenlein, M. (2010). Users of the world, unite! the challenges and opportunities of social media. Business Horizons, 53(1), 59-68.

Karabulut, M. (1981). Tüketici davranış: Pąarlama yeniliklerinin kabulü ve yayılıs̆ı. İstanbul: Minnetoğlu Yayınları.

Katz, D. (1960). The functional approach to the study of attitudes. The Public Opinion Quarterly, 24(2), 163-204.

Kim, S. W. (2009), An investigation on the direct and indirect effect of supply chain integration on firm performance. International Journal of Production Economics, 119(2), 328-346.

Kim, W., Jeong, O.-R. ve Lee, S. W. (2010). On social web sites. Information Systems, 35(2), 215-236.

Koç, E. (2013). Tüketici davranışlar ve pazarlama stratejileri (5. Baskı). Ankara: Seçkin Yayınc1lık. 
Koçak, N. G. (2012). Bireylerin sosyal medya kullanım davranıslarmın ve motivasyonlarmın kullammlar ve doyumlar yaklaşımı bağlamında incelenmesi: Eskişebir'de bir uygulama (Yüksek Lisans Tezi). Anadolu Üniversitesi, Sosyal Bilimler Enstitüsü, Eskişehir.

Kotler, P. (2000). Marketing management. Millenium Edition, U.S.A.: Pearson Prenctice Hall İnc.

Kotler, P., Wong, V., Saunders, J. ve Armstrong, G. (2005). Principles of marketing. Fourth European Edition, England/Spain: Pearson Prentice Hall.

Köker, N. E. ve Maden, D. (2012), Hazc1 ve faydacı tüketim bağlamında tüketicinin ürün temelli yenilikçiliği algilaması: ampirik bir araştırma. İsletme Araştırmalar Dergisi, 4(2), 94-121.

Köksal, Y. ve Özdemir, Ş. (2013). Bir iletişim aracı olarak sosyal medya'nın tutundurma karması içerisindeki yeri üzerine bir inceleme. Süleyman Demirel Üniversitesi İktisadi ve İdari Bilimler Fakültesi Dergisi, 18(1), 323-337.

Kükrer, Ö. (2011). Üniversite öğrencilerinde hedonik tüketimin cinsiyete göre farklılaşması. Karadeniæ. Teknik Üniversitesi İletişim Araştırmalar Dergisi, 1(1), 78-87.

Leung, L. (2001). College student motives for chatting on ICQ. New Media \& Society, 3(4), 483-500.

Mathews, C., Ambroise, L. ve Brignier, J. M. (2009). Hedonic and symbolic consumption perceived values: opportunities for innovators and designers in the fields of brand and product design. Renaissance \& Renewal in Management Studies, Liverpool, United Kingdom, 1-32.

Mayer, R. C., Davis, J. H. ve Schoorman, F. D. (1995). “An integrative model of organizational trust. Academy of Management Review, 20(3), 709-734.

Mayfield, A.. What is social media, icrossing, e-book, s. http://www.icrossing.co.uk/fileadmin/uploads/eBooks/What_is_Social_Media_iCrossing_ebook.pdf, Erişim Tarihi: 08.06.2020.

Meydan, C. H. ve Şeşen, H. (2011). Yapısal eşitlik modellemesi AMOS uygulamalar. Ankara: Detay Yayıncılık.

Odabaş1, Y. (2000). Satıșta ve paz̧arlamada müşteri ilişkileri yönetimi. İstanbul: Sistem Yayınc1lık.

Odabaşı, Y. ve Barış, G. (2007). Tüketici davranısıı. 7. Baskı, İstanbul: MediaCat.

Odabaş1, Y. (2009). Tüketim këlltürü: Yetinen toplamdan tüketen topluma. İstanbul: Sistem Yayınc1lı.

Okada, E. M. (2005). Justification effects on consumer choice of hedonic and utilitarian goods. Journal of Marketing Research, XLII, 43-53.

Onaran, B., Bulut, Z. A. ve Özmen, A. (2013). Müşteri değerinin, müşteri tatmini, marka sadakati ve müşteri ilişkileri yönetimi performansı üzerindeki etkilerinin incelenmesine yönelik bir araştırma. Business and Economics Research Journal, 4(2), 37-53.

O'Shaughnessy, J. ve O'Shaughnessy, N. J. (2002). Marketing the consumer society and hedonism. European Journal of Marketing, 36(5/6), 524-547.

Öz, M. (2011). İş hayatında başarının iki temel koşulu: tüketici davranışlarını anlayabilmek ve müşteri memnuniyetini sağlamak. Uluslararası Sosyal ve Ekonomik. Bilimler Dergisi, 1(2), 95-99.

Özdemir, Ş. ve Yaman, F. (2007). Hedonik alışverişin cinsiyete göre farklılaşması üzerine bir araştırma. Eskiş̧ebir Osmangazi Üniversitesi IIBF Dergisi, 2(2), 81-91.

Perrault Jr., W. D., Cannon, J. P. ve McCarthy, E. J. (2013). Pazarlamann temelleri: Bir pazarlama stratejisi planlama yaklaşımı. 13. Baskıdan Çeviri (Çev. Edt: A. Günal Önce, Çev: S. Yıldız ve E. Yıldız). Ankara: Nobel Yayın Dağıtım.

Petljak, K. Stulec, I. ve Rudawska, E. (2015). Hedonic or utilitarian buying behaviours - what values do young adult customers seek in online group buying?. International Journal of Business Performance Management, 16(2/3), 182-197.

Sarıtaş, A. (2018). Hedonik alışverişin bazı demografik değişkenler açısından incelenmesine yönelik bir alan araştırması. Uluslararası Sosyal Bilimler Dergisi, 2(13), 35-47.

Shiv B., Edell, J. A., ve Payne, J. W. (1997). Factors affecting the impact of negatively and positively framed ad messages. Journal of Consumer Research, 24(3), 285-294.

SI, S. (2016). Social media and its role in marketing. Business and Economics Journal, 7(1), 1-5.

Solomon, M., Bamossy, G., Askegaard, S. ve Hogg, M. K. (2006). Consumer behaviour: A European perspective. England: Prentice Hall.

Şahin, A. ve Fırat A. (2018). Bireylerin hedonik tüketim davranışlarına sosyal medyanın etkisi. Turkish Journal of Marketing, 3(2), 127-142.

Şen, Ş. ve Boyraz, E. (2017). Annelik rolü ve çocuk için tüketime yansımaları: kadınların ebeveynlik tutumları ve hedonik tüketim eğilimi üzerine bir araştırma. KSÜ Sosyal Bilimler Dergisi, 14(2), 347-370.

Şengün, H. İ. ve Karahan, M. (2013). Hedonik (hazcı) tüketim alışkanlıkları ve tüketicileri bu tür alışkanlıklara motive eden nedenler. Dicle Üniversitesi İktisadi ve İdari Bilimler Fakültesi Dergisi, 2(4), 13-26.

Şimşek, Ö. F. (2007). Yapısal eşitlik modellemesine giriş temel ilkeler ve LISREL uygulamalar. 1. Bask1, Ankara: Ekinox.

Tek, Ö. B. (1999). Pazarlama ilkeleri: Global yönetimsel yaklaşım türkiye uygulamalarn (8. Bask1). İstanbul: Beta.

Terkan, R. (2014). Sosyal medya ve pazarlama: tüketicide kalite yansıması. Organizasyon ve Yönetim Bilimleri Dergisi, 6(1), 57-71.

Toksarı, M., Mürütsoy, M. ve Bayraktar, M. (2014). Tüketici algılarını etkileyen faktörlerde sosyal medyanın rolü: Niğde Üniversitesi İ.İ.B.F. örneği. Uşak Üniversitesi Sosyal Bilimler Dergisi, 7(4), 1-28.

Topçu, E. (2017). Tedarik żinciri entegrasyonunun müsteri tatmini ve işletme performansı üzerine etkileri (Yüksek Lisans Tezi). Sakarya Üniversitesi, Sosyal Bilimler Enstitüsü, Sakarya. 
Turanl1, M., Taşpınar Cengiz, D. ve Bozkır, Ö. (2012). Faktör analizi ile üniversiteye giriş sınavlarındaki başarı durumuna göre illerin sıralanması. Istanbul Üniversitesi İktisat Fakültesi Ekonometri ve İstatistik Dergisi, 17, 45-68.

Tütüncü, Ö. (2001). Yiyecek içecek işletmelerinde müsteri tatminin ölçülmesi. Ankara: Turhan Kitabevi Yayınlar1.

Ünal, S. (2008). İggüdüsel alışveriş. Ankara: Detay Yayıncılık.

Voss, K. E., Spangenberg, E. R. ve Grohmann, B. (2003). Measuring the hedonic and utilitarian dimensions of consumer attitude. Journal of Marketing Research, XL, 310-320.

Yağcı, M. İ. ve İlarslan, N. (2010). Reklamların ve cinsiyet kimliği rolünün tüketicilerin satın alma davranışları üzerindeki etkisi. Doğuş Üniversitesi Dergisi, 11(1), 138-155.

Yalın, E. E. (2019). Hedonik tüketim davranşlarnda sosyal medyamn rolü: afyon kocatepe üniversitesi ögrencileri üzerine bir araştırma (Yüksek Lisans Tezi). Afyon Kocatepe Üniversitesi, Sosyal Bilimler Enstitüsü, Afyonkarahisar.

Yıldız, E. ve Avcı, İ. (2019). İnstagram fenomenlerinin görsel ve sözel paylaşımlarının marka tutumu, marka değiştirme ve elektronik kulaktan kulağa pazarlama üzerine etkisi. Uluslararası İktisadi ve İdari İncelemeler Dergisi, 25, 179-198.

Zeithaml, V., Bitner, M. J. ve Gremler, D. (2017). Services marketing: Integrating customer focus across the firm (7. Edition). Boston: McGraw-Hill.

\section{EXTENDED ABSTRACT}

The aim of this study is to investigate the effect of social media on hedonic consumption and the effect of hedonic consumption on consumer attitude and satisfaction. The research covers consumers who resides in Sakarya and who shop online. Consumers use the internet intensively due to the rapid spread of internet use and the convenience it provides. Therefore, companies have to do effective marketing studies in this field. Companies focus on making the shopping process enjoyable for them, as well as offering price, quality and convenience to consumers in order to support their online sales. For this purpose, they design websites, organize activities that will make consumers feel happy, provide information on goods and services through social media channels, make product promotions, and use social media phenomena and well-known people to carry out these activities. They aim to ensure consumer satisfaction with the products and the shopping process and develop a positive attitude towards the business or brand. This research is important in terms of determining the effect of social media use on hedonic shopping and the effect of their shopping for this purpose on their satisfaction levels and attitudes towards the business.

A questionnaire was applied to consumers who live in Sakarya and who shop online. Validity and reliability tests were performed. The convenience sampling method (stratified non-random sample) was used to represent highly the main population of the selected sample. A total of 391 participants were reached and interviewed face to face. Structural equation modeling further was deployed to analyze the data. The first part of the questionnaire consists of demographic questions about the participants' age, gender, marital status, occupation, educational status and income status. In the second part, there are questions about the participants' social media behaviors, hedonic shopping behaviors, attitudes and satisfaction levels. There are 26 questions in the survey to measure the social media usage behavior of the participants. These questions were adapted from the scale developed by Leung (2001). The questions to determine hedonic behaviors were adapted from the scale developed by Arnold and Reynolds (2003) are 23. The questions used to determine participants' attitudes towards shopping websites were adapted from the scale developed by Shiv, Edell ve Payne(1997). There are 4 questions to determine the attitude in the survey. There are 5 questions in the questionnaire to determine the satisfaction level of the participants. These questions were adapted from the questions taken from Topçu (2017)'s study. Topçu (2017) took these questions from the studies of Kim (2009) and Alfalla-Luque, Marin-Garcia ve Medina-Lopez(2014). The data obtained from the survey were analyzed in SPSS 21 and AMOS 24 programs.

All three hypotheses are supported. Social media has a positive effect on hedonic consumption. Hedonic consumption also has a positive effect on consumer attitude and satisfaction. The results show that the managers of companies that sell online should use social media effectively and correctly. Customers influence other customers by sharing their opinions about the goods and services they purchase on social media sites. Companies should use social media platforms effectively to mobilize their customers' hedonic motives and respond to their expectations. Consumers interact on social media to come across with new experiences and new adventures. Hedonic consumers are affected by the prestige of products and services and they are consumed for this purpose. Hedonic consumers, who prioritize the benefits of hedonic factors, make their choices accordingly. For this reason, companies should carry out marketing activities that will appeal to the hedonic motives of consumers by highlighting features such as 
the attractiveness of the website, the attractiveness of the advertisements, the prestige of the product, and the product being a symbol of social status.

Although there are many studies on social media, hedonic consumption, consumer attitude and satisfaction, there are not many studies examining the effect of social media on hedonic consumption and the effect of hedonic consumption on consumer attitude and satisfaction. Overall, it is generally accepted that consumers' use of social media influences their hedonic behavior. However, there is a little research in Turkey on the impact of social media on the hedonic consumption.

We think that this study will make significant contribution to the literature on social media, hedonic consumption, consumer attitude and satisfaction. It is an important constraint that the research is conducted only on users residing in a city center. Conducting future studies on a wider area, on more different consumer groups and more participants, and comparing their results with existing studies will provide significant contributions to the literature. 